\title{
Review \\ Biochemical and Immunological implications of Lutein and Zeaxanthin
}

\author{
Javaria Zafar ${ }^{1}$, Amna Aqeel ${ }^{1}$, Fatima Iftikhar Shah ${ }^{1}$, Naureen Ehsan ${ }^{1}$, Umar Farooq Gohar ${ }^{1}$, \\ Marius Alexandru Moga ${ }^{2}\left[\right.$, Dana Festila ${ }^{3, *} \mathbb{0}$, Codrut Ciurea ${ }^{2, *}$, Marius Irimie ${ }^{2} \mathbb{D}$ and Radu Chicea 4
}

check for updates

Citation: Zafar, J.; Aqeel, A.; Shah, F.I.; Ehsan, N.; Gohar, U.F.; Moga, M.A.; Festila, D.; Ciurea, C.; Irimie, M.; Chicea, R. Biochemical and Immunological implications of Lutein and Zeaxanthin. Int. J. Mol. Sci. 2021, 22, 10910. https://doi.org/10.3390/ ijms222010910

Academic Editors: Raffaele Capasso, Rafael Cypriano Dutra and Elisabetta Caiazzo

Received: 5 September 2021

Accepted: 3 October 2021

Published: 9 October 2021

Publisher's Note: MDPI stays neutral with regard to jurisdictional claims in published maps and institutional affiliations.

Copyright: (c) 2021 by the authors. Licensee MDPI, Basel, Switzerland. This article is an open access article distributed under the terms and conditions of the Creative Commons Attribution (CC BY) license (https:/ / creativecommons.org/licenses/by/ $4.0 /)$.
1 Institute of Industrial Biotechnology, Government College University Lahore, Lahore 54000, Pakistan; javariazafar614@gmail.com (J.Z.); amna.aqeel45@gmail.com (A.A.); microbiologisthashmi@gmail.com (F.I.S.); ehsannoreen@gmail.com (N.E.); dr.mufgohar@gcu.edu.pk (U.F.G.)

2 Faculty of Medicine, Transilvania University of Brasov, 500036 Brasov, Romania; moga.og@gmail.com (M.A.M.); marius_irimie2002@yahoo.com (M.I.)

3 Radiology and Maxilo Facial Surgery Department, Iuliu Hatieganu University of Medicine and Pharmacy, 400012 Cluj Napoca, Romania

4 Faculty of Medicine, “Lucian Blaga” University, 550169 Sibiu, Romania; radu.chicea@gmail.com

* Correspondence: dana.festila@gmail.com (D.F.); codrut_ciurea@yahoo.com (C.C.)

\begin{abstract}
Throughout history, nature has been acknowledged for being a primordial source of various bioactive molecules in which human macular carotenoids are gaining significant attention. Among 750 natural carotenoids, lutein, zeaxanthin and their oxidative metabolites are selectively accumulated in the macular region of living beings. Due to their vast applications in food, feed, pharmaceutical and nutraceuticals industries, the global market of lutein and zeaxanthin is continuously expanding but chemical synthesis, extraction and purification of these compounds from their natural repertoire e.g., plants, is somewhat costly and technically challenging. In this regard microbial as well as microalgal carotenoids are considered as an attractive alternative to aforementioned challenges. Through the techniques of genetic engineering and gene-editing tools like CRISPR/Cas9, the overproduction of lutein and zeaxanthin in microorganisms can be achieved but the commercial scale applications of such procedures needs to be done. Moreover, these carotenoids are highly unstable and susceptible to thermal and oxidative degradation. Therefore, esterification of these xanthophylls and microencapsulation with appropriate wall materials can increase their shelf-life and enhance their application in food industry. With their potent antioxidant activities, these carotenoids are emerging as molecules of vital importance in chronic degenerative, malignancies and antiviral diseases. Therefore, more research needs to be done to further expand the applications of lutein and zeaxanthin.
\end{abstract}

Keywords: macular carotenoids; antioxidants; bioavailability; genetic engineering; CRISPR/Cas9; lutein binding protein

\section{Introduction}

Nature is a dexterous and prolific chemist cataloging 100,000 natural products from plants and microbes. This assortment has noticeably influenced the health and well-being of living beings by treating infectious diseases for thousands of years. Their tremendously diverse counterparts have been employed as colorants, fragrances, spices, aphrodisiacs, toxins, and cosmetics. Dietary carotenoids that entail natural lipophilic pigments with an assembly of $\mathrm{C} 40 \mathrm{H} 56$ have an extensive presence in nature and are also significant contributors to different realms of life [1]. This astounding structural diversity has made them capable of evolving $\geq 750$ naturally occurring carotenoids [2] which play a significant role in guarding the photosynthetic apparatus from surplus light energy in plants and also participates in light harvesting. While in humans and animals, certain cyclic oxycarotenoids, i.e., lutein $(\mathrm{L})$ and zeaxanthin $(\mathrm{Z})$, are vastly accumulated as macular pigments in the retina 
and act not only as an imperious precursor for vitamin A, natural colorants, additives in food or feed industry but also as an essential non-toxic chemo-preventive agent against human cancer by modifying immunological responses [3].

Lutein $\left(3 R, 3^{\prime} R, 6^{\prime} R-\beta, \varepsilon\right.$-caroten-3, $3^{\prime}$-diol) and zeaxanthin ( $3 R, 3^{\prime} R-\beta, \beta$-caroten-3, $3^{\prime}$-diol) are considered as the key macular carotenoids that consist of the basic C40 isoprenoid moiety along with ionone ring at each terminal end carrying hydroxyl groups at 3 and $3^{\prime}$ positions. Apart from these two, meso-zeaxanthin has also been a glare of concern as it is an intermediary isomer of lutein but carries a slightly varying structure from lutein and zeaxanthin [4]. These carotenoids in the retina, especially with higher concentration in the foveal groove (0.1-1 mM), act as antioxidants or the blue light filters against oxidative stress, which is a consequence of excessive light exposure [5]. The ratio of lutein: zeaxanthin: meso-zeaxanthin in the peripheral retina measured by HPLC is about 3:1:0. However, the concentration of aforementioned carotenoids rises 100-fold in macular lutea and the ratio changes to 1:1:1 [6].

Apart from retina, lutein is present in a number of human tissues. They make up about $0.1-1.23 \mu \mathrm{M}$ level of serum, $0.1-3.0 \mu \mathrm{M}$ in the liver, $0.037-2.1 \mu \mathrm{M}$ in kidney and 0.1-2.3 $\mu \mathrm{M}$ in lungs [7]. However, lutein and zeaxanthin cannot be fabricated de novo, even though Homo sapiens devour $\sim 50$ carotenoids in the diet, and $\leq 20$ different carotenoids are usually found in the serum [8]. Usually, green leafy vegetables abundant in lutein and zeaxanthin maintain their level in the retinal tissues, serum, and adipose tissues [9]. The concentration of carotenoids in serum tends to reflect their most recent intakes, whereas adipose tissues are the good indicator of long-term inputs. Since, these macular carotenoids have a decisive role in preventing ophthalmological disorders like age-related macular degeneration (AMD), retinitis pigmentosa, and cataracts [10]. The world concern has shifted its concern towards the formulation of $\mathrm{L}$ and $\mathrm{Z}$ rich products to exploit their role in therapeutic applications.

The global market for carotenoids has previously been expected to grow at approximately US $\$ 1400$ million in the year 2017. It would reach $\$ 2000$ million by 2022 with an annual growth rate of 5.7\% during 2017-2022 [11]. In this regard, lutein extricated from Marigold Flowers (Tagetes erecta) has acquired a top status in the fastest-growing carotenoid market. But the lutein content of Marigold flowers is near to the ground $\left(0.3 \mathrm{mg}^{-1} \mathrm{DW}\right)$, and hence microbes are being looked up for an alternative source of this xanthophyll [12]. The global market expects a reach of EUR 409 million by 2027 for lutein at a Compound Annual Growth Rate (CAGR) of 6.10\% over the projected time frame of 2020-2027 [13]. Likewise, the global zeaxanthin value is expected to reach US\$ 210 Million by 2030, at a CAGR of 8.2\% [14] (Figure 1). However, the lutein and zeaxanthin application in the food industry is limited because of the unstable nature and chemical changes usually faced during food processing [15].

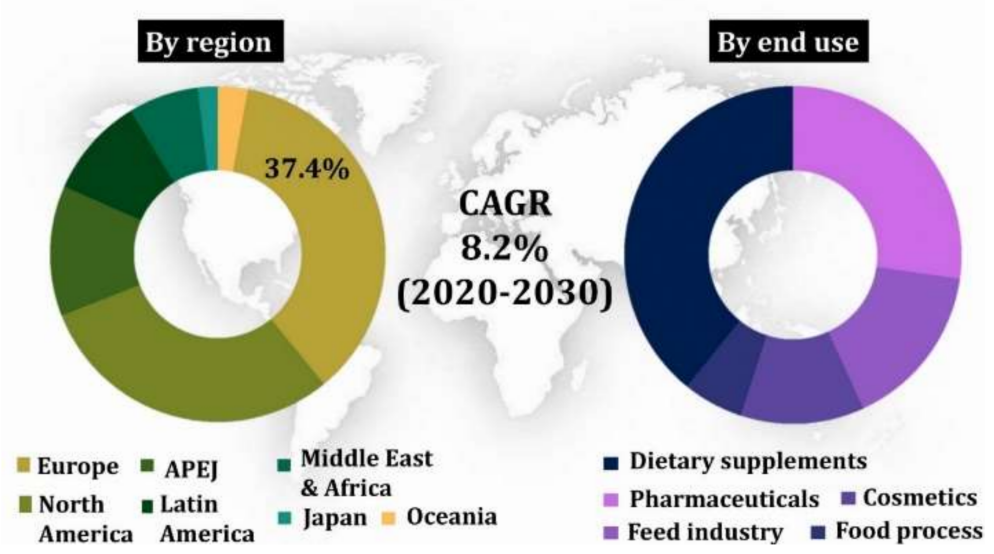

Figure 1. Global Zeaxanthin Market share by region and end use (2020-2030) with compound annual Growth rate of $8.2 \%$. Source: (Transparency Market Research, 2020) [14]. 
Various techniques are being employed to minimize the loss of carotenoid content during food processing and storage. These mainly include freezing, addition of antioxidants and removal of oxygen in a vacuum-sealed/airtight container [16]. In addition, protein engineering techniques have recently been employed to enhance the shelf-life and activity of lutein and zeaxanthin. This review will highlight the bioavailability of lutein and zeaxanthin in different domains of life, along with the engineering of these carotenoids to make them applicable for healthcare and industrial applications.

\section{Lutein and Zeaxanthin in Different Kingdoms of Life}

The carotenoids derived from plastids in plants are generally isoprenoid-derived molecules. Here, several nuclear-encoded enzymes aid the production of these carotenoids [17]. Usually, the biosynthesis of carotenoids takes place through two different mechanisms. These involves the well-explained mevalonate pathway (MVP) in florae [18], and recently studied methylerythritol 4-phosphate (MEP) pathway that often take place in eubacteria including Escherichia coli (shown in Figure 2) [19]. An alternative or non-mevalonate pathway, known as the deoxyxylulose-5-phosphate (DOXP) pathway or MEP pathway, tends to produce isoprenoid precursors, i.e., isopentenyl diphosphate (IPP) and dimethylallyl diphosphate (DMAPP) in plant chloroplast, algae and cyanobacteria etc. that ultimately reach the carotenoid synthesis pathway [20]. In addition, Arigoni et al. [21] have also illustrated the non-mevalonate pathway in Catharanthus roseus for the biosynthesis of lutein, $\beta$-carotene, and phytol.
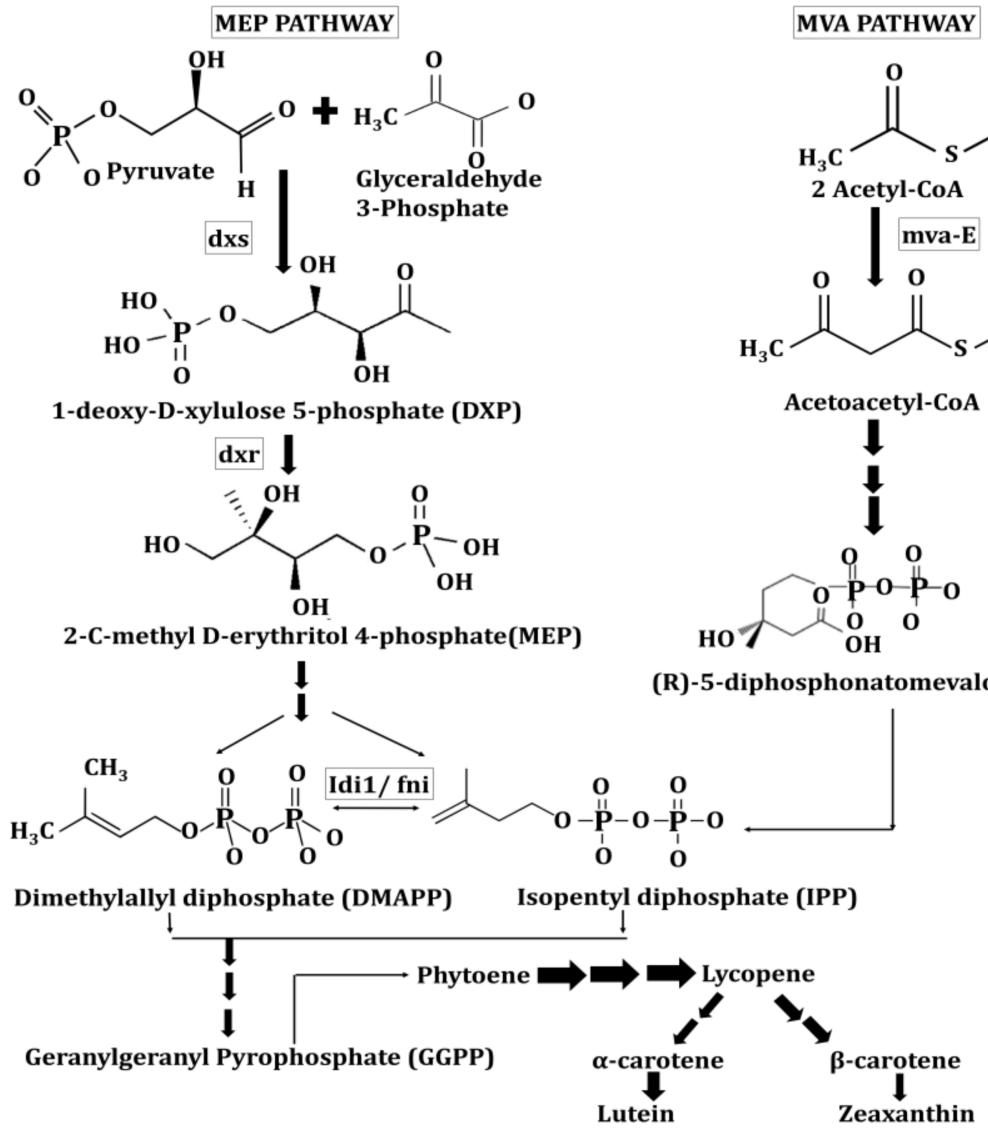

Figure 2. A simplified schematic representation of Biosynthesis of Lutein and Zeaxanthin via both Methylerythritol4-phosphate (MEP) and mevalonate (MVA) pathway. DMAPP and IPP, precursors for $\alpha-, \beta$-carotene are synthesized via both of these pathway. Enzymes involved in the process include: $\mathrm{dxs}$ : deoxyxylulose 5-phosphate synthase; dxr, deoxyxylulose 5-phosphate reductoisomerase; idi1: Isopentyl-diphosphate-isomerase 1; mva-E: Acetyl Co-A acetyl transferase. 


\subsection{Biosynthesis and Presence of Lutein and Zeaxanthin in Kingdom Plantae and Animalia}

Photosystem II is a critical player in photosynthesis, and its photo-protection is thus a matter of utmost importance to alleviate the light-induced damage mediated by the generation of reactive oxygen species (=photo-oxidative stress). Naturally occurring carotenoids are notable for their ability to neutralize the effect of triplet chlorophyll $\left(3 \mathrm{Chl}^{*}\right)$ and singlet oxygen $\left(1 \mathrm{O}_{2}^{*}\right)$ [22]. Usually, Carotenoids having cyclic end groups and $\beta$ - and $\varepsilon$-rings are consistently prevalent in the reaction centers of photosynthetic organisms like algae, plants, and cyanobacteria. The catalytic machinery accountable for catalyzing the generation of $\beta$ - and $\varepsilon$-rings is encoded by distantly related ( $36 \%$ identity for the deduced amino acid sequences) single-copy genes of Arabidopsis thaliana [23]. Thereof, carotenoids with $\beta$ - and one $\varepsilon$-ring are regarded as lutein in floral species. In this regard, Bialek-Bylka et al. [24] have stated the prevalence of lutein's central cis-isomer in a prominent light-harvesting domain of Photosystem II of higher plants (e.g., spinach). Here, these carotenoids have played a significant role in quenching triplet chlorophyll and thus playing a substantial role in photo-protection.

The lutein production from lycopene follows four staged enzymatic reactions. These reactions involve $\beta$ - and $\varepsilon$-ring cyclization and hydroxylation of each ring at the C-3 position. For this purpose, three enzymes have already been identified in Arabidopsis and regarded as carotenoid hydroxylases. The two non-heme di-iron $\beta$-ring monooxygenases (the B1 and B2 loci) are involved in catalyzing the hydroxylation of the $\beta$-ring in $\beta, \beta$-carotenoids, and one heme-containing monooxygenase (CYP97C1, the LUT1 locus) catalyzes the hydroxylation of $\varepsilon$-ring of $\beta, \varepsilon$-carotenoids [25]. However, recently, it has been documented that Arabidopsis CYP97A3 (the LUT5 locus) encodes another carotenoid hydroxylase with distinct in vivo activity towards the $\beta$-ring of $\alpha$-carotene ( $\beta, \varepsilon$-carotene) and negligible activity on $\beta$-rings of $\beta$-carotene ( $\beta, \beta$-carotene). Hence, Kim et al. [26] have reported a most anticipated pathway for lutein synthesis in plants (as shown in Figure 3): that follows the ring cyclizations for $\alpha$-carotene production. After the hydroxylation of $\beta$-ring at $\alpha$-carotene by CYP97A3 for the generation of zeinoxanthin, succeeded by $\varepsilon$-ring hydroxylation of zeinoxanthin by CYP97C1, lutein can be harvested.

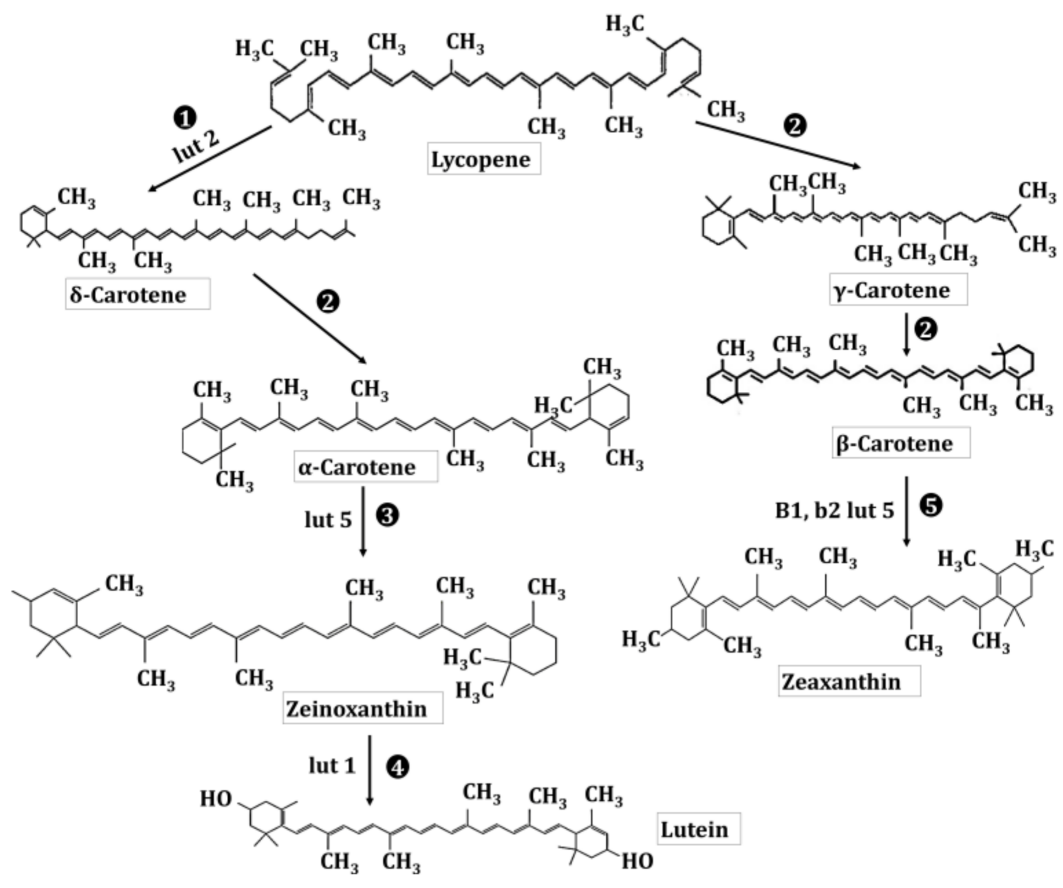

Figure 3. Pathway showing the most preferred routes of lutein biosynthesis in Arabidopsis. Enzymatic reactions are indicated by numbers; 1 : $\varepsilon$-cyclization by ation, 3 : $\beta$-hydroxylation of carotenoids, 4: $\varepsilon$-ring hydroxylation, 5: $\beta$ - ring hydroxylation of $\beta, \beta$-carotenoids by CYP97A3 (lut 5 locus). Modified from Kim et al. [26]. 
Furthermore, the carotenoids having two $\beta$-rings, i.e., $\beta$-carotene and zeaxanthin, are also omnipresent and are contemplated as the photo-protective agents against the excess light. There is a similarity in the mainstream mechanism of lutein synthesis, ring cyclization followed by hydroxylation, to its neighboring structural isomer, zeaxanthin. Usually, nonheme B1 and B2 $\beta$-ring hydroxylases are involved in the formation of zeaxanthin, while lutein results from P450-mediated $\alpha$-carotene ring hydroxylases activity [26]. With a momentous role in protecting chlorophyll, zeaxanthin is also a key player in the lipid bilayer of the plant membrane (or most probably at the protein-membrane interface) [27].

However, the bioavailability of lutein and zeaxanthin may differ on the basis of vegetable or fruit type (Table 1). The lutein concentration in the natural sources relies on the kind, maturity level, processing technique, and storage time of food [28]. Interestingly, only traces of zeaxanthin have been found in most dark green vegetables, including scallions, green lettuce, celery, spinach, and brussels sprouts [29]. However, the qualitative portrayal of lutein in green vegetables is essentially the same except for romaine lettuce that carries a significant amount of another dihydroxycarotenoid, lactucaxanthin ( $\varepsilon, \varepsilon$-carotene-3,3'-diol) [30].

Unlike plants, animals cannot synthesize carotenoids but can receive them from diet and transform them into various forms. The oxidative metabolites of lutein; papirioerythrinon, philosamiaxanthin (3-hydroxy- $\beta, \varepsilon$-caroten- $3^{\prime}$-one), and fritschiellaxanthin exist in various species of butterflies and moths [31]. Maoka et al. [32] investigated Heteroptera (assassin bugs, stink bugs, water scorpions, water striders, backswimmers, and water bugs) from a chemo- systematic and chemical ecological perspective. It appeared that lutein, $\beta$-carotene and, $\beta$-cryptoxanthin procured from plants were prevalent in both stink bugs and leafhoppers.

Similarly, Czeczuga [33] has reported a number of carotenoids in multiple species of Lepidoptera. These include lycopene, zeaxanthin, $\beta$-cryptoxanthin, and lutein epoxide. The most prevalent carotenoid in butterflies, known as zeaxanthin, is formed from the $\beta$-carotene or $\beta$-cryptoxanthin, absorbed from food, as its epoxide form is less dominant in higher plants than lutein. Furthermore, dragonflies of the order Odonata have gained attention for their carotenoid content and courage, strength, victory and happiness in Japan [34]. In their larval form, the dragonflies, i.e., Anisoptera and Zygoptera, carry lutein, $\beta$-carotene, $\beta$-cryptoxanthin, and fucoxanthin. Dragonfly larvae nourishing on aquatic creatures; tadpoles, water fleas, and small fish, derive their carotenoid content from them. The adult dragonfly of Anisoptera and Zygoptera carry a significant portion of $\beta$-carotene along with lutein, zeaxanthin, echinenone, and $\beta$-caroten-2-ol [35]. Hence, food chain investigations suggest that adult dragonflies carry lutein and zeaxanthin from their feed which includes flies, butterflies, mosquitoes, moths, spiders, and plant-hoppers.

Table 1. Occurrence of lutein and zeaxanthin in different parts of plants.

\begin{tabular}{|c|c|c|c|c|c|c|}
\hline Source & Common Names & $\begin{array}{l}\text { Concentration } \\
\text { of Lutein } \\
(\mathrm{mg} / \mathbf{1 0 0 g})\end{array}$ & $\begin{array}{c}\text { Concentration } \\
\text { of } \\
\text { Zeaxanthin } \\
\text { (mg/100g) }\end{array}$ & $\begin{array}{c}\text { Cumulative } \\
\text { Concentration of } \\
\text { Lutein }+ \\
\text { Zeaxanthin } \\
\text { (mg/100g) }\end{array}$ & $\begin{array}{c}\text { General } \\
\text { Applications }\end{array}$ & Reference \\
\hline \multicolumn{7}{|c|}{ Vegetables: } \\
\hline \multirow{2}{*}{$\begin{array}{l}\text { Asparagus } \\
\text { officinalis L. }\end{array}$} & \multirow{2}{*}{$\begin{array}{l}\text { Garden asparagus/ } \\
\text { Sparrow grass }\end{array}$} & \multicolumn{2}{|c|}{ Cooked asparagus } & \multirow{2}{*}{$\begin{array}{c}0.382-0.653 \\
\text { (in raw asparagus) }\end{array}$} & \multirow{2}{*}{$\begin{array}{l}\text { Antioxidant } \\
\text { property }\end{array}$} & \multirow{2}{*}[36,37]{} \\
\hline & & 0.991 & 0.22 & & & \\
\hline $\begin{array}{l}\text { Asparagus } \\
\text { acutifolius }\end{array}$ & Wild asparagus & $0.544-1.913$ & N.A & N.A & $\begin{array}{c}\text { Nutritional } \\
\text { supplements }\end{array}$ & {$[38]$} \\
\hline \multirow{2}{*}{$\begin{array}{l}\text { Brassica oleracea } \\
\text { var. italica }\end{array}$} & \multirow{2}{*}{ Broccoli } & \multicolumn{2}{|c|}{ Cooked broccoli } & \multirow{2}{*}{1.079} & \multirow{2}{*}{$\begin{array}{l}\text { Antioxidant } \\
\text { property }\end{array}$} & \multirow{2}{*}[39,40]{} \\
\hline & & $3.11-3.960$ & 1.73628 & & & \\
\hline
\end{tabular}


Table 1. Cont.

\begin{tabular}{|c|c|c|c|c|c|c|}
\hline Source & Common Names & $\begin{array}{l}\text { Concentration } \\
\text { of Lutein } \\
(\mathrm{mg} / 100 \mathrm{~g})\end{array}$ & $\begin{array}{l}\text { Concentration } \\
\text { of } \\
\text { Zeaxanthin } \\
(\mathrm{mg} / 100 \mathrm{~g})\end{array}$ & $\begin{array}{c}\text { Cumulative } \\
\text { Concentration of } \\
\text { Lutein }+ \\
\text { Zeaxanthin } \\
(\mathrm{mg} / 100 \mathrm{~g})\end{array}$ & $\begin{array}{c}\text { General } \\
\text { Applications }\end{array}$ & Reference \\
\hline $\begin{array}{c}\text { Solanum nigrum } \\
\text { L. }\end{array}$ & $\begin{array}{l}\text { European black } \\
\text { nightshade }\end{array}$ & 84.38 & N.A & N.A & $\begin{array}{c}\text { Nutritional } \\
\text { supplements }\end{array}$ & [41] \\
\hline $\begin{array}{c}\text { Hibiscus } \\
\text { cannabinus L. }\end{array}$ & Kenaf & 104.24 & 4.59 & N.A & $\begin{array}{l}\text { Antioxidant } \\
\text { property }\end{array}$ & [42] \\
\hline Capsicum annuum & Green chilies & 1.902 & 0.06285 & 13.74 & $\begin{array}{l}\text { Antioxidant } \\
\text { property }\end{array}$ & [43] \\
\hline $\begin{array}{l}\text { Solanum } \\
\text { tuberosum }\end{array}$ & Potato & $\begin{array}{l}0.1352- \\
0.1524\end{array}$ & 0.0077 & N.A & $\begin{array}{l}\text { Nutritional } \\
\text { supplement }\end{array}$ & {$[44,45]$} \\
\hline Daucus carota L. & Wild carrot & 40.17 & 0.59 & N.A & $\begin{array}{l}\text { Antioxidant } \\
\text { property }\end{array}$ & [37] \\
\hline Lactuca sativa & Lettuce & 3.824 & N.A & 2.313 & $\begin{array}{l}\text { Ophthalmological } \\
\text { significance }\end{array}$ & [37] \\
\hline \multicolumn{7}{|c|}{ Herbaceous parts } \\
\hline $\begin{array}{c}\text { Ocimum basilicum } \\
\text { L. }\end{array}$ & Basil & $4.2-8.3$ & $0.2-0.6$ & $6.634 \pm 0.410$ & $\begin{array}{l}\text { Nutritional } \\
\text { supplements }\end{array}$ & {$[46,47]$} \\
\hline $\begin{array}{l}\text { Petroselinum } \\
\text { crispum }\end{array}$ & Parsley & 4.326 & 1.236 & 5.562 & $\begin{array}{c}\text { Nutritional } \\
\text { supplements }\end{array}$ & [48] \\
\hline $\begin{array}{l}\text { Coriandrum } \\
\text { satioum }\end{array}$ & Coriander & 9.920 & N.A & $4.740 \pm 4.36$ & $\begin{array}{l}\text { Adjuvants in food } \\
\text { preparation }+ \\
\text { antioxidants }\end{array}$ & {$[43,49]$} \\
\hline Mentha spicata & Spearmint & 17.74 & 0.28 & 18.00 & $\begin{array}{l}\text { Nutritional } \\
\text { supplement }\end{array}$ & {$[41,43]$} \\
\hline $\begin{array}{c}\text { Elattaria } \\
\text { cardamomum }\end{array}$ & $\begin{array}{l}\text { Green or true } \\
\text { cardamom }\end{array}$ & 0.44 & N.A & 0.35 & $\begin{array}{l}\text { Antioxidant } \\
\text { property }\end{array}$ & [50] \\
\hline \multicolumn{7}{|c|}{ Fruits } \\
\hline $\begin{array}{l}\text { Malpighia } \\
\text { emarginata }\end{array}$ & Barbados Cherry & $9.20 \pm 0.23$ & $1.14 \pm 0.03$ & N.A & $\begin{array}{l}\text { Antioxidant } \\
\text { property }\end{array}$ & [51] \\
\hline Cucurbita maxima & Pumpkin & 10.62 & 0.278 & N.A & $\begin{array}{l}\text { Antioxidant } \\
\text { property }\end{array}$ & [50] \\
\hline $\begin{array}{c}\text { Solanum } \\
\text { lycopersicum }\end{array}$ & Tomato & 0.289 & 0.0144 & 94 & $\begin{array}{l}\text { Antioxidant } \\
\text { property }\end{array}$ & [37] \\
\hline Citrus X sinensis & Orange & 0.033 & 0.029 & 0.129 & $\begin{array}{l}\text { Antioxidant } \\
\text { property }\end{array}$ & [37] \\
\hline $\begin{array}{c}\text { Vitis vinifera 'Red } \\
\text { Globe' }\end{array}$ & Red grapes & 0.024 & 0.004 & N.A & $\begin{array}{l}\text { Antioxidant } \\
\text { property }\end{array}$ & \\
\hline \multicolumn{7}{|c|}{ Seed/Grain } \\
\hline Zea mays L. & Corn & 1.47 & 0.01031 & $0.01662-0.02057$ & $\begin{array}{l}\text { Antioxidant } \\
\text { property }\end{array}$ & {$[52,53]$} \\
\hline Triticum durum & Whear & $1.5-4.0$ & 0.00049 & N.A & $\begin{array}{l}\text { Nutritional } \\
\text { supplmenets }\end{array}$ & {$[54,55]$} \\
\hline
\end{tabular}

\subsection{Prevalence of Lutein and Zeaxanthin in Kingdom Protista- Algae and Fungi}

Microbes are notable for assembling various bioactive compounds that possess an exceptional therapeutic potential and stand out as an emerging source of profitable secondary metabolites. The carotenoids present in microalgae have their role as accessory 
pigments in the photosystems and act as the fundamental unit of light-harvesting systems with a role in phototaxis and as photo-protection [56]. Lutein is present within the members of Chlorophyta, Cryptophyta, Chlorarachniophyta, Rhodophyta, and Euglenophyta [57]. Del-Campo et al. [56] have reported the prominent lutein content in fifteen strains of Chlorophyceae, including Chlorella fusca SAG 211-8b, Chlorococcum citriforme SAG 62.80, Muriellopsis sp., Neospongiococcum gelatinosum and Chlorella zofingiensis CCAP 211/14. Moreover, microalgae, such as Chlorella zofingensis and Chlorella protothecoides with a lutein concentration of $0.13 \%$, and $4.6 \%$ per dry weight, have emerged as the alternative reservoirs of lutein [58]. Nevertheless, members of the class Bangiophyceae in red algae, such as the Porphyra/Pyropia species, have a carotenoid profile dominated by lutein along with $\alpha$-carotene, $\beta$-carotene, and zeaxanthin [59]. The red algae are characterized for utilizing the DOXP pathway to synthesize of lutein and zeaxanthin (as shown in Figure 3). Similarly, the order Euglenida has been under the spotlight for its potential as a feedstock to produce biodiesel and carotenoids. Recently, Deli et al. [60] have reported the production of $23.7 \%(w / v)$ lutein in E. sanguinea, a ubiquitous resident of various shallow and eutrophic freshwater bodies. In addition, certain growth conditions (e.g., temperature, $\mathrm{pH}$, irradiance, availability, nitrogen source, salinity or ionic strength) also favor the high carotenoids production (up to $13 \% w / w)$ in the green algae Dunaliella salina. This alga assembles $\beta$-carotene, zeaxanthin, astaxanthin, cryptoxanthin and lutein [61,62]. Table 2 demonstrates the microalgal species that are involved in the fabrication of lutein and zeaxanthin.

Table 2. Production of lutein and zeaxanthin by micro-algal species.

\begin{tabular}{|c|c|c|c|c|c|c|}
\hline Microalgae & $\begin{array}{l}\text { Culture } \\
\text { Conditions }\end{array}$ & Biomass & $\begin{array}{l}\text { Lutein } \\
\text { Yield }\end{array}$ & $\begin{array}{l}\text { Zeaxanthin } \\
\text { Yield }\end{array}$ & Other Carotenoids & References \\
\hline \multicolumn{7}{|c|}{ Division Chlorophyta } \\
\hline $\begin{array}{c}\text { Chlorella } \\
\text { pyrenoidosa }\end{array}$ & $\begin{array}{l}\text { Fresh water } \\
\text { cultures }\end{array}$ & N.A & $\begin{array}{c}125034.4 \\
\mu \mathrm{g} / \mathrm{g}\end{array}$ & $2170.3 \mu \mathrm{g} / \mathrm{g}$ & $\begin{array}{c}\text { cis isomers of } \beta \text {-carotene, all } \\
\text { trans- } \beta \text {-carotene, } \\
\text { cisisomers of } \alpha \text {-carotene, } \beta \\
\text {-cryptoxanthin, neoxanthin } \\
\text { and its cis isomers, } \\
\text { neochrome, auroxanthin, } \\
\text { violaxanthin and its cis } \\
\text { isomers }\end{array}$ & [63] \\
\hline $\begin{array}{l}\text { Chlorella } \\
\text { sorokiniana }\end{array}$ & $\begin{array}{l}\text { Fresh water } \\
\text { cultures }\end{array}$ & $1.98 \mathrm{~g} / \mathrm{L} / \mathrm{d}$ & $6490 \mu \mathrm{g} / \mathrm{g})$ & N.A & Astaxanthin & [64] \\
\hline Chlorella salina & $\begin{array}{l}\text { Fresh water } \\
\text { cultures }\end{array}$ & $665.89 \mathrm{mg}$ & $\begin{array}{c}9.73 \\
\mathrm{mg} / \mathrm{L} / \text { day }\end{array}$ & N.A & N.A & [65] \\
\hline $\begin{array}{l}\text { Chlorella } \\
\text { zofingiensis }\end{array}$ & $\begin{array}{l}\text { Fresh water } \\
\text { cultures }\end{array}$ & $7 \mathrm{~g} / \mathrm{L}$ & $4000 \mu \mathrm{g} / \mathrm{g}$ & $\begin{array}{c}7000 \pm 820 \\
\mu \mathrm{g} / \mathrm{g}\end{array}$ & $\begin{array}{l}\text { monoester of astaxanthin } \\
\text { and canthaxanthin }\end{array}$ & {$[66,67]$} \\
\hline Chlorella vulgaris & $\begin{array}{l}\text { Fresh water } \\
\text { cultures }\end{array}$ & N.A & $3360 \mu \mathrm{g} / \mathrm{g}$ & N.A & $\begin{array}{c}\text { Astaxanthin } 12.5 \% \mathrm{TC} \\
\text { violaxanthin }\end{array}$ & [68] \\
\hline $\begin{array}{l}\text { Dunaliella salina } \\
\text { zea1 (mutant) }\end{array}$ & Fresh water & N.A & N.A & $200 \mu \mathrm{g} / \mathrm{g}$ & $\begin{array}{l}\text { Astaxanthin and } \\
\text { violaxanthin }\end{array}$ & [69] \\
\hline $\begin{array}{c}\text { Chlorella } \\
\text { protothecoides }\end{array}$ & Fresh water & $19.6 \mathrm{~g} / \mathrm{L}$ & $\begin{array}{c}68.42 \text { and } \\
83.81 \mathrm{mg} / \mathrm{L}\end{array}$ & N.A & N.A & [70] \\
\hline \multicolumn{7}{|c|}{ Division Rhodophyta } \\
\hline $\begin{array}{c}\text { Porphyra } \\
\text { acanthophora var. } \\
\text { brasiliensis }\end{array}$ & Saline condition & N.A & $\begin{array}{c}4.16-30.71 \\
\mu \mathrm{g} / \mathrm{g}\end{array}$ & $\begin{array}{l}4.43-36.31 \\
\mu \mathrm{g} / \mathrm{g}\end{array}$ & N.A & {$[71]$} \\
\hline
\end{tabular}


Table 2. Cont.

\begin{tabular}{|c|c|c|c|c|c|c|}
\hline Microalgae & $\begin{array}{l}\text { Culture } \\
\text { Conditions }\end{array}$ & Biomass & $\begin{array}{l}\text { Lutein } \\
\text { Yield }\end{array}$ & $\begin{array}{c}\text { Zeaxanthin } \\
\text { Yield }\end{array}$ & Other Carotenoids & References \\
\hline Pyropia yezoensis: & Marine culture & & $\begin{array}{c}3460570 \\
\mu \mathrm{g} / \mathrm{g}\end{array}$ & $\begin{array}{c}2.36-17.58 \\
\mu \mathrm{g} / \mathrm{g}\end{array}$ & $\begin{array}{c}\alpha \text {-carotene, } \alpha \text {-cryptoxanthin } \\
\left(\beta, \varepsilon \text {-caroten- } 3^{\prime} \text {-ol }\right), \text { and } \\
\text { zeinoxanthin } \\
(\beta, \varepsilon \text {-caroten-3-ol })\end{array}$ & [72] \\
\hline Porphyra sp. & Marine culture & N.A & $\begin{array}{c}430-1117 \\
\mu \mathrm{g} / \mathrm{g}\end{array}$ & N.A & N.A & [73] \\
\hline Corallina elongata & Marine culture & N.A & $1.3 \pm 0.6 \%$ & $4.7 \pm 0.1 \%$ & Anteraxanthin & {$[74]$} \\
\hline $\begin{array}{l}\text { Rhodymenia } \\
\text { corallina. }\end{array}$ & Marine Culture & N.A & $\begin{array}{c}3.4 \pm 0.3 \\
\mu \mathrm{g} / \mathrm{g} \\
\text { ision Euglen }\end{array}$ & $\begin{array}{l}\text { N.A } \\
\text { phyta }\end{array}$ & $\begin{array}{l}\text { Trans- } \beta \text {-carotene, } \\
\text { Cis- } \beta \text {-carotene, }\end{array}$ & [75] \\
\hline Euglena gracilis & Fresh water & $0.5 \mathrm{~g} / \mathrm{L}$ & $\begin{array}{c}700 \\
\mathrm{mg} / 100 \mathrm{~g}\end{array}$ & N.A & Neoxanthin and $\beta$-carotene. & [76] \\
\hline
\end{tabular}

Fungi is another alternative source of natural pigments due to their multiple advantages over plants. These include fast and easy growth, season-independent production of stable and soluble pigments, and varying shades of color [77]. Numerous filamentous fungus generates various carotenoids and xanthophylls (e.g., lycopene, carotene) (e.g., astaxanthin, lutein, zeaxanthin, and violax). Kingdom fungi produce carotenoids via mevalonate pathway, which utilizes 5-carbon isopentenyl pyrophosphate (IPP) as a precursor. This IPP is produced from hydroxymethylglutaryl coenzyme A (HMG-CoA) or derivatives of 1-deoxy-D-xylulose 5-phosphate (DXP) or 2-C-methyl-D-erythritol (MEP) [78].

Over the past two decades, several studies have been carried out on various oleaginous fungi that serve on naturally occurring sources of carotenoids. These include Neurospora crassa, M. hiemalis, Blakeslea trispora, Phycomyces blakesleeanus, and M. circinelloides [79]. In this regard, Mohamed et al. [80] have performed the comparative investigation of oleaginous Mucoromycota Fungi for their carotenoid potential. Genus Mucoromycota entails typical oleaginous filamentous fungus that forms valuable carotenoids and essential fatty acids. The investigation revealed that M. hiemalis AUMC 6031 and M. hiemalis AUMC 6695 took lead by the highest yield of total carotenoids $(640 \mu \mathrm{g} / \mathrm{g})$ with a similar profile of zeaxanthin $(34 \%)$, $\beta$-carotene (65\%), canthaxanthin, and astaxanthin (5\%), in regards of total carotenoids concentration. Similarly, Rodríguez-Sáiz et al. [81] have reported the presence of the crtS gene for the formation of zeaxanthin and $\beta$-cryptoxanthin in Mucor circinelloides. Thus, fatty acids and carotenoids procured from oleaginous microbes have a potential to bring revolution in various therapeutic applications.

\subsection{Biosynthesis of Lutein and Zeaxanthin in Domain Eubacteria}

A vast repertoire of microorganisms is considered as the distinct reservoir of various valuable products. These organisms appear to be a reliable alternative against plant-based carotenoids due to enhanced productivity, availability throughout the year, and ease in maintaining desired conditions during the fermentation process. In addition, transforming a low-cost substrate (industrial or agricultural waste) into high-value carotenoids recapitulate our commitment to turning waste into gold. The prokaryotic nature of bacteria allows genetic manipulations more easily in contrast with the eukaryotic plants and algae. Several promising bacterial strains in freshwater and marine waters have been reported for having myriad of carotenoids. Around 30 bacterial isolates belonging to Chryseobacterium, Arthrobacter, Zobellia, and Flavobacterium genera identified from King George island, Antarctica, carry ten different carotenoids with the most frequent ones include $\beta$-carotene, zeaxanthin, and $\beta$-cryptoxanthin [82]. The biological route followed for zeaxanthin extraction is from marigold (Tagetes erecta) flowers. Nevertheless, the generated zeaxanthin is of low purity, since the extract contained only $20 \%$ of trans-zeaxanthin and varying 
concentrations of other carotenoids, waxes, fats, and oils [83]. A comparative study has revealed that zeaxanthin isolated from microbial (e.g., Flavobacterium multivorum) source has 2-3 times more bio-availability than the less stable ones from marigold flowers [84].

Among these various taxa, the family of Enterobacteriaceae (e.g., Enterobacter and Erwinia/Pantoea genera) are the foremost producers of zeaxanthin and its derivatives such as zeaxanthin $\beta$-glycoside [85]. Similarly, Entophytic microbes are a plenteous source of numerous bioactive natural products. Fidan and Zhan [86] have reported an endophytic bacterium, Pseudomonas sp. 102515, from the leaves of Taxus chinensis which is a significant producer of zeaxanthin diglucoside. Although some of the bacterial species (listed in Table 3) have been identified as zeaxanthin producers, their commercial scale production is yet to be established.

Table 3. Production of zeaxanthin in domain eubacteria.

\begin{tabular}{|c|c|c|c|c|c|}
\hline Family Name & Microorganism & $\begin{array}{l}\text { Major } \\
\text { Carotenoid } \\
\text { Content }\end{array}$ & Other Carotenoids & General Applications & References \\
\hline \multirow{7}{*}{ Flavobacteriaceae } & $\begin{array}{c}\begin{array}{c}\text { Flavobacterium sp. P8 } \\
\text { strain }\end{array} \\
\text { a }\end{array}$ & $205 \mu \mathrm{g} / \mathrm{g}$ & $\begin{array}{c}\beta \text {-cryptoxanthin and } \\
\beta \text {-carotene }\end{array}$ & $\begin{array}{c}\text { Prevention of macular } \\
\text { degeneration }\end{array}$ & [87] \\
\hline & \multirow[b]{2}{*}{$\begin{array}{l}\text { Flavobacterium } \\
\text { multivorum }\end{array}$} & $\begin{array}{c}(0.05 \\
\mu \mathrm{g} / \mathrm{mL} / \mathrm{h})\end{array}$ & $\begin{array}{c}\beta \text {-cryptoxanthin and } \\
\beta \text {-carotene }\end{array}$ & Antioxidant & [88] \\
\hline & & $\begin{array}{c}10.65 \pm 0.63 \\
\mu \mathrm{g} / \mathrm{mL}\end{array}$ & $\begin{array}{c}\beta \text {-cryptoxanthin and } \\
\beta \text {-carotene }\end{array}$ & $\begin{array}{c}\text { For commercialization } \\
\text { of zeaxanthin based } \\
\text { products }\end{array}$ & [89] \\
\hline & Flavobacterium sp. & $1 \mathrm{mg} / \mathrm{L}$ & $\begin{array}{c}\beta \text {-cryptoxanthin and } \\
\beta \text {-carotene }\end{array}$ & $\begin{array}{l}\text { Natural food colorant } \\
\text { for fish and poultry }\end{array}$ & [90] \\
\hline & $\begin{array}{c}\text { Mesoflavibacter } \\
\text { zeaxanthinifaciens }\end{array}$ & $0.91 \mathrm{mg} / \mathrm{g}$ & $\begin{array}{l}\text { Yellow carotenoid } \\
\text { pigments }\end{array}$ & $\begin{array}{l}\text { For use as a natural } \\
\text { colorant in feed industry }\end{array}$ & [91] \\
\hline & $\begin{array}{c}\text { Mesoflavibacter aestuarii } \\
\text { sp. }\end{array}$ & $\begin{array}{c}1200 \mathrm{mg} / 100 \\
\mathrm{mg}\end{array}$ & N.A & Antioxidant & [92] \\
\hline & $\begin{array}{c}\text { Aquibacter } \\
\text { zeaxanthinifaciens }\end{array}$ & N.A & $\begin{array}{l}\text { Some unidentified } \\
\text { carotenoids }\end{array}$ & Antioxidant & [93] \\
\hline \multirow{2}{*}{ Enterobacteriaceae } & $\begin{array}{l}\text { E. coli (metabolic } \\
\text { engineered strain) }\end{array}$ & $1.6 \mathrm{mg} / \mathrm{g}$ & $\beta$-carotene & Antioxidant & [94] \\
\hline & E. coli & $11.95 \mathrm{mg} / \mathrm{g}$ & $\begin{array}{c}\beta \text {-cryptoxanthin and } \\
\beta \text {-carotene }\end{array}$ & Antioxidant & [95] \\
\hline Sphingobacteriaceae & $\begin{array}{c}\text { Nubsella } \\
\text { zeaxanthinifaciens }\end{array}$ & $0.8 \mathrm{mg} / \mathrm{g}$ & N.A & Natural colorant & [96] \\
\hline
\end{tabular}

Despite being the potential source of pigments, cyanobacteria are also involved in the large-scale production of phycocyanin from Arthrospira platensis. The reason involves the insignificant level of carotenoid content in cyanobacteria compared to vascular plants or microalgae [97]. However, recently Morone et al. [98] have reported the potential of ethanol extracts of picocyanobacterial strains of the genera Cyanobium and Synechocystis and filamentous strains of the genera Nodosilinea, Phormidium, and Tychonema for skin applications. The obtained carotenoids involve canthaxanthin, $\beta$-carotene and echinenone, with zeaxanthin and lutein being the most abundant ones (49.82 and $79.08 \mu \mathrm{g} \mathrm{g}^{-1}$, respectively). Thus, the ethanol extracts obtained from Cyanobium and Tychonema sp. are identified as the potential candidates for anti-aging formulations, as they trigger the proliferation of fibroblast and inhibit the digestion of hyaluronic acid. 


\section{Enhancing the Production of Lutein and Zeaxanthin by Genetic Engineering Approach}

The importance of carotenoids in human health and nutrition has led to various efforts in increasing their level in food crops. Traditionally, lutein is produced through the solvent extraction procedure of lutein esters, mediated with saponification [99]. Khachik [100] has revealed a procedure of purgation and recrystallization of lutein from saponified marigold oleoresin. But this strategy involved several solvents for extraction and purification steps. Another investigation involved the saponification of crude oleoresin from marigold extract using ethanol, water, and $45 \%$ alkali for $3-5 \mathrm{~h}$ at $45-80{ }^{\circ} \mathrm{C}$ [101]. This process had a higher yield but appeared uneconomical due to the high concentration of alkali and the minor content of lutein ester in substrate. Even though, organic solvents have previously been utilized to process biomaterials, there are concerns over their implications in the environment and food industry. Since the transcriptional regulation of carotenogenic genes is a vital strategy for accumulating carotenoids in plants, global attention has been directed towards metabolic/genetic engineering techniques for the enhanced production of lutein and zeaxanthin.

\subsection{Engineering Biosynthetic Pathway of Lutein by Random Mutagenesis Approach}

Altering the growth metabolism of microalgae through genetic engineering techniques is a vital strategy for enhanced lutein production under phototrophic, heterotrophic, and mixotrophic growth conditions [102]. Chen et al. [103] have revealed the random mutagenesis mediated variants of wild type Chlorella sorokiniana MB-1 for lutein extraction. By adding $6.0 \mathrm{~g} / \mathrm{L}$ of sodium acetate under mixotrophic conditions, the C. sorokiniana MB-1 wild type strain produced lutein content of $2.39 \mathrm{mg} / \mathrm{L}$ per day and $5.86 \mathrm{mg} / \mathrm{g}$ per day. This indicate the fact that under same culture condition, the MB-1-M12 mutant strain generated a greater lutein content $(7.52 \mathrm{mg} / \mathrm{g}$ and $3.63 \mathrm{mg} / \mathrm{L} /$ day) as opposed to wild type strain. Thus, developing the microalgal strains with an inbuilt capacity to generate a higher lutein content is crucial for commercialization of microalgal-mediated lutein.

In addition, Cordero et al. [12] have reported that the random mutagenesis by Nmethyl-N'-nitro-nitrosoguanidine (MNNG) of $C$. sorokiniana give rise to higher lutein levels. The produced mutants were screened for resistance against the carotenogenic pathway inhibitors, i.e., nicotine and norflurazon. Consequently, mutant MR-16 depicted a higher level of cellular lutein content than the wild-type strains. The produced MR-16 mutant showed nicotine resistance activity by acting as a specific inhibitor of the lycopene $\beta$ cyclase that could have a capacity to alter the specific activity of this mutant by adding an altered assembly for the herbicide-binding site. This ultimately resulted in higher enzyme activity and improved production of lutein under the photoautotrophic conditions. Additionally, this mutant's higher growth rate is attributed to the increased lutein content under photoautotrophic growth conditions than the wild type strain. This carotenoid is notable for its role in photosynthetic assembly's structure, function and photo-protection. Thus, paving the way towards an efficient photosynthetic pathway.

\subsection{Engineering Biosynthetic Pathway of Lutein and Zeaxanthin by Gene Assembly Approach}

A number of unique carotenoids have been synthesized by assembling carotenoid biosynthetic genes from various living entities and expressing these "hybrid" mechanisms in a recombinant host is a unique approach for tomorrow's sustainability [104]. By introducing appropriate gene clusters into noncarotenogenic host, Escherichia coli, carotenoid production can be improved [105]. Recently, Nishizaki et al. [106] have attempted to optimize the zeaxanthin production by reordering the five biosynthetic genes in Pantoea ananatis. In this regard, recently outlined operons for zeaxanthin production were fabricated by the technique of ordered gene assembly in Bacillus subtilis (OGAB), which can accumulate multiple genes in one step using an intrinsic B. subtilis plasmid transformation system. Increased zeaxanthin formation in E. coli $(820 \mathrm{~g} / \mathrm{g}$ [dry weight]) was found in transformants carrying a plasmid with genes arranged in an order of zeaxanthin metabolic pathway (crtE-crtB-crtI-crtY-crtZ). These results strengthen the utilization of the OGAB method as a unique approach to reorder $c r t$ genes for the production of carotenoids. This 
pathway opens the door for the application of various operons having desired gene order in investigating metabolic pathways.

Similarly, Choi et al. [85] have also demonstrated that the recombinant E. coli with six carotenoid biosynthesis genes ( $\mathrm{crtE}, \mathrm{crtB}, \mathrm{crtI}, \mathrm{crtY}, \mathrm{crtZ}$, and $\mathrm{crtX}$ ) of Pantoea ananatis can produce a novel carotenoid glycoside that has a characteristic carbohydrate moiety, quinovose (chinovose; 6-deoxy-D-glucose). Later, this carotenoid glycoside was recognized as 3- $\beta$-glucosyl-3'- $\beta$-quinovosyl zeaxanthin through spectroscopic and chromatographic analysis. These zeaxanthin glycosides were appeared as $3 R, 3^{\prime} R$ aglycones with hydroxyl groups added by the CrtZ enzyme. Later, it was revealed that zeaxanthin synthesized from $\beta$-carotene via CrtR or CYP175A1 had the same stereochemistry as CrtZ.

In an attempt to obtain a high yield of zeaxanthin from photoautotrophic prokaryotes like E. coli, another system, i.e., Synechocystis sp. strain PCC 6803, has come into the limelight that overexpress the biosynthetic genes of carotenoids. This system comprises of the $p s b \mathrm{AII}$ gene, which encodes the highly expressed photosystem II D1 protein with a strong promoter. Upon further examination of the Synechocystis genome, it is discovered that three genes, namely $p s b \mathrm{AI}, p s b \mathrm{AII}$, and $p s b \mathrm{AIII}$, encode the D1 protein. Even in the truancy of the other two $p s b \mathrm{~A}$ genes, $p s b \mathrm{AII}$ and $p s b \mathrm{AIII}$ may express independently and sustain photoautotrophic growth [107]. Thus, the psbAII locus can be utilized as an integration system to overexpress the genes residing in Synechocystis. Later in the psbAII coding sequence, Lagarde et al. [108] introduced the yeast isopentenyl diphosphate isomerase (ipi), $\beta$-carotene hydroxylase (crtR), phytoene desaturase and phytoene synthase genes of Synechocystis (crtP andcrtB). Overexpression of the crtP and crtB genes resulted in a 50\% increase in the myxoxanthophyll and zeaxanthin content of the mutant strain. Moreover, the overexpression of $c r t R$ triggered a 2.5 -fold increase in zeaxanthin in the mutant strain compared to the wild-type strain. Thus, altering genes expression by inducing over-expression or the deletion of specific genes is a successful approach for changing the carotenoid content of cyanobacteria. Additionally, the assembly method used in this system is capable of replacing genes without introducing antibiotic resistance cassettes. Therefore, the absence of such cassettes in these strains marks the future of the ultimate desire of the biotechnology industry to avoid the spread of antibiotic resistance genes cassettes.

Cyanobacteria produce a vast range of products that mainly include $\beta$-carotene, zeaxanthin, echinenone and myxoxanthophyll [109]. In contrast to zeaxanthin, lutein and the $\alpha$-branch of the MEP pathway are absent in cyanobacteria However, Lehmann et al. [110] created a genetically modified cyanobacterium Synechocystis that lacks the MEP $\alpha$-branch required for lutein synthesis. In this regard, a cassette encompassing four Arabidopsis thaliana genes encoding two lycopene cyclases (AtLCYe and $A t L C Y b$ ) and hydroxylases (AtCYP97A and AtCYP97C) was established into a Synechocystis strain, that had a dearth of endogenous cyanobacterial lycopene cyclase $c r u A$. This specie produced increased amount of lutein, which aided in the investigation of lutein-associated activities such as the assembly of plant-type light-harvesting complexes and other carotenoidsbinding proteins.

\subsection{Enhanced Production of Zeaxanthin by CRISPR/Cas 9 Based Approaches}

Zeaxanthin is a remarkable pigment for retina and antioxidant activities. Since zeaxanthin aids in the preclusion of age-related macular degeneration, its utilization at commercial scale for implication in nutrition and therapeutics has been explored most seriously in these times. However, in order to cater with healthcare problems, it is vital to produce zeaxanthin of high purity.

Genetic engineering techniques have wide-ranged applications in the phenomenon of carotenogenesis, as they carry a significant potential to increase the commercial status of carotenoids. Recently, the green alga Chlamydomonas reinhardtii has acquired utmost consideration for being a photosynthetic factory, but its role in carotenoid production has not yet been revealed. Over the course of time, the diversity of carotenoid mutants 
of $C$. reinhardtii has initiated the discovery of genes involved in lutein and zeaxanthin biosynthesis [111].

Since there are several strains of $C$. reinhardtii with exceptional traits but CC-4349 is an incredible host for the pigment and carotenoid formulation. In this regard, Baek et al. [112] have produced the knock-out mutant of the zeaxanthin epoxidase gene with the help of DNAfree CRISPR-Cas9 ribonucleoproteins in CC-4349. Resultantly, the produced mutant depicted a substantially elevated zeaxanthin concentration (56-fold) with increased productivity by 47-folds compared to the wild type without undermining lutein concentration. These findings clearly indicate to the prospect of commercializing micro-algal mutants through DNA-free CRISPR-Cas9 ribonucleoproteins to produce high-value goods in a low cost.

Similarly, Song et al. [113] have revealed a CRISPR-Cas9 ribonucleoprotein mediated double knockout mutant of $C$. reinhardtii. The modification was made to the lycopene epsilon cyclase (LCYE) gene in order to remove the $\alpha$-branch of xanthophyll biosynthesis in a zeaxanthin epoxidase knockout variant (ZEP). After three days of cultivation, the double knockout mutant produced $60 \%$ more zeaxanthin $\left(5.24 \mathrm{mg} \mathrm{L}^{-1}\right)$ with a content of $\left(7.28 \mathrm{mg} \mathrm{g}^{-1}\right)$ than the acquired parental line. In nutshell, this research entails solutions to overcome the pitfalls of down-stream processes in the production of highly pure zeaxanthin.

\subsection{Regulation of Biosynthetic Pathways of Lutein and Zeaxanthin by Carotenoid Desaturases Cyclases}

In the carotenoid biosynthetic pathway, $\zeta$-carotene desaturase (ZDS) and carotenoid isomerase (CRTISO) allow the conversion of $\zeta$-carotene to the lycopene, which is a substrate for two competing lycopene cyclases, $\varepsilon$-LCY, and $\beta$-LCY. In the past, ZDS gene has not been studied to improve the carotenoids content in plants. Additionally, its function in toleratings abiotic stresses has not yet been revealed. Nevertheless, Li et al. [114] have stated that the overexpression of IbZDS gene in the Ipomoea batatas brings forth a significant increase in the lutein contents (1.74-2.37-folds) and $\beta$-carotene (2.24-3.96-folds) contents along with increased salt tolerance in the transgenic sweet potato. Similarly, Phytoene desaturase (PDS), the structural coherent of ZDS, is the key player of lutein biosynthetic pathway. In the biosynthetic pathway of lutein, this enzyme allows the transformation of colorless phytoene to the colorful carotenoids in algae and plants.

In this regard, Li et al. [3] have revealed that by employing random and site-directed mutagenesis in PDS, a single amino acid mutation (N144D) functions in the activity of enzyme. This mutant produced an inactive enzyme, thus implying the fact that amino acid 144 is vital for PDS enzymatic activity. Moreover, Fantini et al. [115] have recently revealed that the virus-induced gene silencing (VIGS) of PDS in tomatoes results in the reduction of $55 \%$ total carotenoid content (including lutein), with phytoene and phytofluene as the most prevalent ones.

Moreover, $\varepsilon-L C Y$ and $\beta$-LCY direct the lycopene flux towards $\alpha$ - and $\beta$-branch of the carotenogenic pathway and produce $\alpha$-carotene and $\beta$-carotene [116]. These two cyclases are interlinked closely and stem out through the phenomenon of ancient gene duplication. Several studies of these two cyclases revealed that separate genes in plants encode them. Usually, a single gene encodes a fusion protein of LCYB, LCYE, and a C-terminal light-harvesting complex (LHC) domain in the prasinophyte algae of the order Mamiellale. However, the ability to tune the product ratio of the Mamiellales' lycopene cyclase fusion protein renders it advantageous for the biotechnological formation of asymmetric carotenoids like $\alpha$-carotene or lutein [117]. Zeng et al. [118] utilized a post-transcriptional gene silencing technique to down-regulate the expression of $T a L C Y B$ in transgenic wheat to explore the function of Lycopene $\beta$-cyclase in the production of lutein. The results demonstrated a decrease in $\beta$-carotene and lutein content that was accompanied by lycopene accumulation to slightly reimburse for the total carotenoid content. This demonstrates the fact that lycopene $\beta$-cyclase, carry a pronounced role in lutein biosynthesis.

In addition, the overexpression of lycopene $\beta$-cyclase (IbLCYB2) in sweet potato, Ipomoea batatas (L.) Lam. categorically enhance $\alpha$-carotene, $\beta$-carotene, zeaxanthin, and $\beta$-cryptoxanthin content with increased tolerance towards drought, salt, and oxidative stress [119]. Figure 4 
illustrates the proposed model for increasing the carotenoids level by overexpressing the LCYB gene in the sweet potato. The Co-overexpression of $d s x$ and $i d i$ genes in the transgenic E. coli has a supplementary effect on the zeaxanthin production that reached $1.6 \mathrm{mg} / \mathrm{g}$ DCW [120]. Moreover, Li et al. [121] also engineered Escherichia coli by utilizing fusion protein-mediated substrate channeling and incorporated tunable intergenic regions to optimize zeaxanthin biosynthesis from lycopene. This approach is more beneficial than protein fusion approach for co-expression of lycopene $\beta$-cyclase gene crtY and $\beta$-carotene 3 -hydroxylase gene crtZ. In a nutshell, the impact of substrate channeling advocates the $\mathrm{CrtZ}$ catalyzed reaction to be the rate-limiting step in the biosynthesis of zeaxanthin.

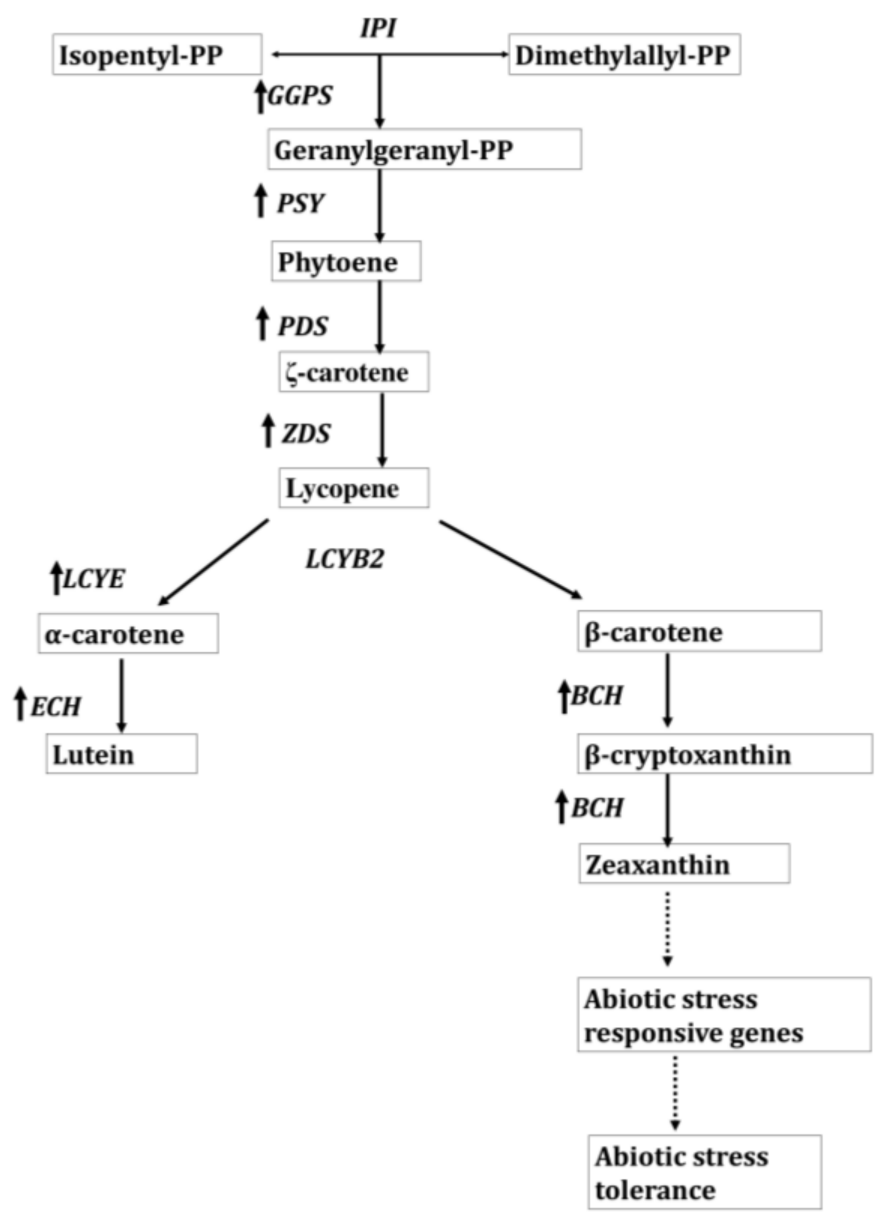

Figure 4. Diagram shows a proposed model for boosting carotenoid biosynthesis and antibiotic stress responses in the transgenic sweet potato plants. The upregulation of enzymes i.e., IPI (isopentyldiphosphate delta isomerase), GGPS (Geranylgeranyl pyrophosphate synthase), PSY (Phytoene synthase), PDS (Phytoene desaturase), ZDS (Zeta-carotene desaturase), LCYE (Lycopene epsilon cyclase), ECH (Enoyl-CoA hydratase), BCH (Beta carotene hydroxylase. Modified from Kang et al. [119].

The lycopene $\varepsilon$-cyclase (LCYE), similar to lycopene $\beta$-cyclase (LCYB), is also involved in the biosynthetic pathway of carotenoids. Tokunaga et al. [122] also overexpressed the LCYE gene in C. reinhardtii to determine its aftermaths on lycopene metabolism and lutein synthesis. Chlamydomonas transformants also produce an increased amount of lutein per culture (up to 2.6-fold) without decreasing cell yields. The overexpression of LCYE increases the transformation of lycopene to $\alpha$-carotene, which results in lutein production. For alterations in carotenoid profile by RNAi mediated decreased expression of lycopene epsilon-cyclase, ( $\varepsilon$-CYC),

Yu et al. [123] reported a shift in carotenoid accumulation within the seeds of B. napus. The bio-engineered seeds expressing this construct experienced an elevated level of zeaxan- 
thin, beta-carotene, violaxanthin, and surprisingly lutein. An elevated level of carotenoid content evolved from decreased expression of $\varepsilon-C Y C$ in seeds implies that this gene is a rate-limiting step in the biosynthetic pathway of carotenoid. Three possibilities comprehensively explain lutein production in an $\varepsilon-C Y C$ mediated silenced lines of B. napus: (1) The presence of additional copies of $\varepsilon-C Y C$ gene that are not silenced by RNAi may compensate for the formation of $\varepsilon$-ring. The southern blot analysis employing enzymes bearing either single or no recognition sites within the cDNA sequence revealed that the genome of B. napus carries at least two homologs of an $\varepsilon$-CYC gene [124]. The identification of these homologs must be done to determine their activity in RNAi silenced and parental tissues. (2) The generation of the $\varepsilon$-ring with the help of enzymes carrying a broad spectrum of the substrate; enzymes bearing the capability of $\varepsilon$-ring formation at the terminals of aliphatic compounds may act as the driving factor for $\varepsilon$-rings formation in lycopene. (3) $\varepsilon$-CYC is not regarded as the rate-limiting gene for lutein biosynthesis in seeds. Still, silencing an $\varepsilon-C Y C$ gene may result changes in the cellular compartments or sequestration molecules, thus enhancing seed capacity to stockpile lutein.

\section{Esterification of Lutein and Zeaxanthin to Enhance the Stability and Bioavailability in Harsh Environmental Conditions}

Lutein esters are widely recognized as the primary carotenoids in marigold petals, extracts, oleoresins, and derivative products. Indeed, several lutein monoesters and diesters acylated with lauric (12:0), myristic (14:0), palmitic (16:0), and stearic (18:0) acid moieties have been characterized, with the major compounds being lutein dimyristate, dipalmitate, myristic-palmitate, and palmitate-stearate [125]. But for most wheat flour products, color is a significant quality criterion. The main component of a creamy bread wheat flour and various other components is the asymmetric dihydroxy carotenoid, lutein, that contributes mainly to the yellow color of yellow alkaline yellow noodles (YAN) [126]. Lutein's role in the yellow and creamy color of end products and contribution towards health and nutrition $[127,128]$ is well documented. However, lutein is degraded directly by heat and light and indirectly by free radicals produced from lipid oxidation $[129,130]$.

Identifying the gene(s) essential for xanthophyll esterification would be beneficial for breeding purposes, as esterified carotenoids have a greater capacity for accumulation inside plant cells and are more stable in the course of post-harvest stowage. In this context, Requena-Ramrez et al. [131] examined five genes in $H$. chilense genome that were identified as potential candidates of xanthophyll acyltransferase (XAT) in lutein esterification. All of these genes expressed themselves in tritordeum during grain growth, but only XAT-7Hch was highly upregulated. Notably, its wheat orthologue TRAESCS7D02g094000 (XAT-7D) has recently identified as the gene encoding XAT enzyme for esterification of lutein [132]. Tritordeum includes a high percentage of endosperm lutein esters and low quantities of durum wheat [124] or no lutein esters at all [133]. As a result, it was proposed that the high fraction of lutein esters in tritordeum has been generated by genes from $H$. chilense genome (Hch). Later, it appeared that XAT-7Hch was a prime match for lutein esterification in H. chilense and Tritordeum. Thus, the transfer of XAT-7Hch to wheat may be beneficial for increasing lutein esters in bio-fortification programs.

Moreover, colloidal delivery systems based on oil, water, and surfactants in the form of micro-emulsions, nanoemulsions, and standard emulsions, are essential for chemical preservation and delivery in food items and drinks. However, environmental friendly and practical techniques of esterification preparation are needed badly. Table 4 shows the stabilizing capacity of different matrices of lutein and zeaxanthin esters. In this respect, Shangguan et al. [134] described the synthesis of lutein esters utilizing a new covalently immobilized lipase B from Candida antarctica onto functionalized graphitic carbon nitride nanosheets. Gombač et al. [135] used viable and accessible procedures to create stable firm encapsulates of lutein and its esters. Lecithin emulsions exhibited higher encapsulation efficiencies, up to $99.3 \%$ for formulations having free lutein and up to $91.4 \%$ for formulations containing lutein esters. Due to the tiny droplet size, resistance to creaminess, and physical 
stability of lecithin emulsions, $17 \%$ and $80 \%$ of lutein and its esters were maintained within the formulations after 250 days.

The majority of commonly consumed fruit and vegetables contain far more concentration of lutein. However, high amounts of zeaxanthin $(Z)$ and specifically zeaxanthin esters have also been reported in several fruits and vegetables [136]. For example, wolfberry, a fruit used to revamp eyesight in Chinese traditional medicine, has zea dipalmitate concentrations that can be $1 \mathrm{~g} / \mathrm{kg}$ of the dry weight [137]. Moreover, chinese lanterns (Physalis alkekengi), orange pepper (Capsicum annum), and sea buckthorn (Hippophae rhamnoides) have been identified as reservoirs of zeaxanthin [136]. Breithaupt et al. [138] have reported a postprandial increase in plasma zeaxanthin when the subjects were fed with zeaxanthin dipalmitate meal than the meal having an equivalent amount of free zeaxanthin. Like lutein, Lam and But [139] have proposed that esterified zeaxanthin takes part in the durability of wolfberry's therapeutic action. As a result of a recent investigation with rodents, esterified zeaxanthin is more bioavailable than the free form [140]. Humphries and Khachik [30] have indicated the total amount of all-trans- and multiple cis isomers of zeaxanthin in fruits after saponification of their extracts. However, there is relatively little information regarding the indigenous zeaxanthin ester pattern. Primary research has been done by Wingerath et al. [141] who studied MALDI mass spectrometry on zeaxanthin esters in tangerine juice. In addition to the esters of $\beta$-cryptoxanthin, zeaxanthin mono palmitate and five zeaxanthin diester(s) have been identified. In tangerine juice, however, the total concentration of zeaxanthin was relatively modest $(1.3 \mathrm{mg} / 100 \mathrm{~g})$.

Table 4. Stabilization potential of lutein and zeaxanthin esters with different matrices.

\begin{tabular}{|c|c|c|c|c|}
\hline Ester & Matrix & Results & Application & References \\
\hline \multicolumn{5}{|c|}{ Lutein } \\
\hline $\begin{array}{c}\omega-3 \text { polyunsaturated } \\
\text { fatty acid esters of } \\
\text { lutein }\end{array}$ & Fish oil & $\begin{array}{l}\text { Better anti-oxidant ability } \\
\text { and augmenting shelf-life }\end{array}$ & $\begin{array}{l}\text { Oral supplements and } \\
\text { nutraceuticals }\end{array}$ & [142] \\
\hline \multirow{4}{*}{ Lutein esters } & Nanoparticles & $\begin{array}{l}\text { Improve ocular delivery } \\
\text { efficiency }\end{array}$ & $\begin{array}{l}\text { Oral drug formulation and } \\
\text { eye-targeted drug delivery } \\
\text { system }\end{array}$ & [143] \\
\hline & Microcapsules & Increased half-life of lutein & For feed industry & [144] \\
\hline & Polyvinylpyrrolidone & $\begin{array}{l}\text { Improved shelf life and } \\
\text { solubility }\end{array}$ & Antioxidant & [145] \\
\hline & $\begin{array}{c}\text { Polyoxyethylene sorbitan } \\
\text { monooleate capsules }\end{array}$ & Improved stability & Ocular delivery system & [135] \\
\hline \multicolumn{5}{|c|}{ Zeaxanthin } \\
\hline $\begin{array}{l}\text { Zeaxanthin } \\
\text { dipalmitate }\end{array}$ & $\begin{array}{l}\text { Sea Buckthorn oil and } \\
\text { water emulsion }\end{array}$ & Increase bioaccesibility & $\begin{array}{c}\text { Functional foods and } \\
\text { nutraceutics }\end{array}$ & [146] \\
\hline Zeaxanthin ester & $\begin{array}{l}\text { Glycyrrhizic acid, } \\
\text { arabinogalactan }\end{array}$ & Solubility enhancement & Food Industry & [147] \\
\hline
\end{tabular}

\section{Thermal Degradation Kinetics and Cold Adaptability of Lutein and Zeaxanthin}

The thermal degradation of lutein, $\beta$-carotene and $\beta$-cryptoxanthin in virgin olive oils is best illustrated by first-order kinetic process (VOO). According to Ruiz et al. [148], thermal stability varies across carotenoids, with lutein having higher thermal stability than $\beta$-carotene and $\beta$-cryptoxanthin with significant changes in geometric configuration. The isokinetic study examined kinetic and thermodynamic parameters (TP) in three Virgin olive oil (VOO) matrices with varying pigment concentration (high, medium, and low), and discovered that the oily medium had no effect on the reaction processes.

Pigment protein complexes (PPCs) of photosynthetic plants (PSA) protect injuries caused by disruption in the balance between light energy absorption and its use in photo- 
synthesis. Leafy plants exposed to stress situations use numerous $\mathrm{Chl}$ and Car protection approaches when the light absorption surpasses the potential of utilizing the light reaction products. During the seasonal change, these mechanisms are coupled with substantial fluctuations in the qualitative and quantitative composition of photosynthetic pigments [149]. Recently, Sofronova et al. [150] have examined the periodic fluctuations in the ratio between photosynthetic pigments of one-year-old needles of Scotch pine (Pinus sylvestris L.). In July, when light and temperature were suitable, maximum accumulation of chlorophylls took place in developing young needles. The needles were noteworthy in this period because of their relatively high $\beta$-carotene and neoxanthin levels and also for their diminished lutein and violaxanthin-cycle pigments (VXC). In autumn hardening, the chlorophyll content decreased twice, but the total carotenoid concentration remained the same. In the start of hardening at lower and above-zero temperatures, there is a decrease in the $\beta$-carotene contents in the needles and the pigment protein complex (PPC) enrich with lutein.

This analysis predicts that when the temperature falls seasonally in the initial phases of hardening, the decline in chlorophyll content promote a decrease in the amount of absorbed radiant energy. Actually, the activation of lutein and neoxanthin in PPC antenna is followed by a gradual drop in the capacity of plants to satiate singlet energy for the excitation of chlorophyll. Due to the back reaction suppression of epoxidation at nearnull temperatures, the accumulation of zeaxanthin allows indispensable prerequisites for turning on the mechanisms that allow absorbed light energy dissipation and do not depend upon the transmembrane proton gradient of thylakoids. Zeaxanthin can also serve as an antioxidant in the PPC and thylakoid membranes during the lipid phase [150]. Such results indicate that the observed reactions are adaptive, and individual pigments play a specific role in photosynthetic machinery's structural and functional reorganization during the development of frost resistance in the needles.

\section{Medicinal Applications of Lutein and Zeaxanthin}

Carotenoids provide a wide range of nutritional and health benefits due to their multifarious biological impacts on humans, which include antioxidative, immunomodulatory, and anti-inflammatory properties [151]. Following are some of the effective implications of lutein and zeaxanthin in human beings.

\subsection{Role of Lutein and Zeaxanthin in Treatment of Cognitive Impairment}

Lutein and zeaxanthin account for $66-77 \%$ of the total carotenoid population in the brain, making them the main players in eye and brain health when compared to other members of the carotenoid family [151]. Lutein and its isomer zeaxanthin have a neurological connection between the macula and the brain, implying a role in cognition [152]. Lutein and zeaxanthin, as MP, are possible biomarkers of brain xanthophyll concentrations [153], and therefore provide information on the concentrations of lutein in the brain, making them a critical biomarker [154]. This includes the relationship with several measures of temporal processing speed [155], which is a necessary component of sensory and cognitive functions such as language, executive function, learning, and memory. A double-blinded, placebo-controlled trial on the cognitive implications of women who were given lutein dose $(12 \mathrm{mg} / \mathrm{d})$, docosahexaenoic acid dose $(800 \mathrm{mg} / \mathrm{d})$, or their combination for the period of 4 months revealed the significant improvement in verbal fluency scores in all 3 groups with boost in memory scores and learning rate [156]. Lutein and zeaxanthin have also been found to improve gap junctional communication [157], which is necessary for light processing and the development of neural circuitry in the visual system in the retina. These are also related with an increase in visual processing speed and a reduction in scotopic noise [158].

\subsection{Role of Lutein and Zeaxanthin in Diabetes}

Lutein may be useful in reversing the diabetic renal injury and inflammation through its anti-apoptotic and free radical scavenging properties. Diabetic nephropathy is a complex condition that results in the formation of free radicals, which act as a potent stimulant for 
pro-inflammatory factors. Lutein in the diet results in a reduction in serum and urine kidney function tests (urea and creatinine), indicating that diabetes-associated renal impairment is ameliorated. Different dose levels significantly reduce kidney inflammatory responses by decreasing TNF-, IL-1, and IL-6 (inflammatory mediators) levels while increasing IL-10 levels (anti inflammtory cytokine). Its supplementation at a greater dose, particularly the higher dose, ameliorate glomerular and tubular diabetes-induced damage and inflammatory infiltrates of renal leucocytes, therefore reducing oxidative and nitrosative stressors in renal tissue [159]. Patients with diabetic retinopathy (DR) group were given $6 \mathrm{mg} / \mathrm{d}$ of lutein with $0.5 \mathrm{mg} / \mathrm{d}$ of zeaxanthin for a period of 3 months with $0.0714 \pm 0.0357 \mu \mathrm{g} / \mathrm{mL}$ of lutein and $0.0119 \pm 0.0072 \mu \mathrm{g} / \mathrm{mL}$ of zeaxanthin in the control. Consequently, serum $\mathrm{L} / \mathrm{Z}$ ratio experienced increase from $0.2816 \pm 0.0731 \mu \mathrm{g} / \mathrm{mL}$ to $0.5409 \pm 0.1807 \mu \mathrm{g} / \mathrm{mL}$ after $\mathrm{L} / \mathrm{Z}$ supplementation as compared to normal individuals. Moreover, a decrease in average foveal thickness was also observed in $83 \%$ of patients. Thus, improving diabetic macular edema, visual acuity (VA) and contrast sensitivity (CS) in DR [160].

\subsection{Role of Lutein and Zeaxanthin in Cancer}

Lutein and $\alpha$-carotene neutralize peroxy radicals through their antioxidative properties [161]. Carotenoids are combined to produce a stouter antioxidant defense as compared to their individual effect. Lutein or lycopene had the sturdiest effect, when combined synergistically [162]. Lutein depict its anti-carcinogenic activity by interacting with the mutagens including 1-nitro pyrene and aflatoxin B1 [163]. Moreover, the aforementioned carotenoid tends to activate specific genes that are involved in T-cell transformations after the spasm of various mitogens, cytokines, and antigens. Slattery et al. [164] detected a negative correlation between dietary lutein consumption and colon cancer in males and females.

Plasma lutein levels in humans are inversely related to cytochrome CYP1A2 activity, an enzymes involved in the metabolic instigation of putative human carcinogens in liver [165]. Lutein has been shown to have chemopreventive action in animal models of colon and breast cancer [166]. Zeaxanthin, lutein, and other carotenoids have been demonstrated to inhinit, dose-dependently. Haegele et al. [167] reported that plasma lutein levels in females is inversely related to oxidative DNA damage (8-hydroxy-2 deoxyguanosine (8-OHdG) in peripheral lymphocytes and lipid peroxidation.

\subsubsection{Treatment of Ovarian Cancer:}

Increased uptake of zeaxanthin and lutein has appeared to be associated with $79 \%$ reduction in ovarian cancer. A number of epidemiologic investigations [168] has stated that zeaxanthin with lutein supplementation reduced ovarian cancer risk by $40-55$ percent. In the Korean population, plasma levels of micronutrients such as B-carotene, lycopene, zeaxanthin, lutein, retinol, and tocopherol have a role in lowering the risk of ovarian cancer [169]

\subsubsection{Treatment of Colorectal Cancer:}

Ras signaling pathway appears to play a role in lutein-induced chemoprevention. Lutein has been known to lower the levels of many proteins involved in cell proliferation, notably K-ras and activated Akt (pPKB), in tumors of animals. Wang et al. [170] demonstrated that Inhibiting PI3K/Akt elicits cell cycle arrest and differentiation in a number of cell types, including the human colon cancer cell lines HT29 and Caco2. On the other hand, mice fed with lutein integrated into their diets and administered with Dimethyl hydrazine $(\mathrm{DMH})$ demonstrated a substantial reduction of aberrant crypt foci (ACF) formation in the colon, which was associated with a decrease in cellular proliferation in terms of 5-bromo2 '-deoxyuridine. As compared to DMH-treated samples, lutein administration before and during DMH treatment reduced the concentration of $\beta$-catenin in colonic samples, hyperplasia, and adenocarcinomas, by acting as an efficient blocking agent. 


\subsubsection{Treatment of Breast cancer}

According to Rock et al. [171] an increased lutein concentration in plasma is directly linked with an increased chance of estrogen receptor positivity in females diagnosed with breast cancer. Lutein substantially reduces the incidence of breast cancer metastasis by causing cell-cycle arrest and caspase-independent cell death, which is quantitatively comparable to the effects caused by chemotherapeutic taxanes and docetaxel. Therefore, it can be stated that exposure of lutein plus taxanes decreases breast cancer cell growth [172]. Lutein results in ROS production in triple-negative breast cancer (TNBC) cells and induce growth-inhibition by its attenuated radical oxygen scavenger, $\mathrm{N}$-acetyl cysteine, thus depicting an ROS mediated growth inhibition on TNBC cells. Moreover, lutein treatment activates the $\mathrm{p} 53$ signaling pathway and increases HSP60 levels, both of which contributes to the growth inhibition in TNBC cells [173]. Low level of dietary lutein i-e 0.002 and $0.02 \%$ fed to mice inhibited the incidence of mammary tumor, its growth as well as latency [174].

\subsection{Role of Lutein and Zeaxanthin in Hepatic Disorders}

Alcoholic liver diseases (ALD) are defined as hepatic injuries induced by excessive alcohol consumption ( $>20 \mathrm{~g}$ ethanol per day) and ranged from steatosis, alcoholic fatty liver disease (AFLD), and alcoholic hepatitis, to alcoholic cirrhosis [175]. Since zeaxanthin dipalmitate (ZD) is the most significant constituent of wolfberry, it is involved in the treatment of AFLD. ZD targets the key membrane receptors $\mathrm{P} 2 \times 7$ and adiponectin receptor 1 (adipoR1) with a dose range of $10 \mathrm{mg} / \mathrm{g}$ in chronic AFLD rat models. $\mathrm{P} 2 \times 7$ and adipoR1 signals therefore regulate the phosphatidylinositol 3-kinase-Akt and/or AMP-activated protein kinaseFoxO3a pathways by restoring the mitochondrial autophagy (mitophagy) that was previously suppressed by ethanol intoxication [176]. Furthermore, ZD lessens hepatic inflammation by blocking Nod-like receptor 3 inflammasome. ZD may also help to reduce and prevent tissue scarring. Oral ZD $(25 \mathrm{mg} / \mathrm{kg})$ prevents secondary fibrosis and lowers collagen levels (including 4-hydroxyproline) in the liver. ZD also restore glutathione S-transferase (GST) activity, which has been proven to bind and neutralize bilirubin ZE (25 mg/kg) also inhibited liver fibrosis [177]. However, the underlying mechanisms remain unknown.

\subsection{Role of Lutein and Zeaxanthin in Pregnancy}

Carotenoids, notably lutein and zeaxanthin, are essential for the development of vision and the neurological system. These carotenoids are required for the improvement of the retinal activity, energy metabolism, and brain electrical activity, along with a few other functions [178].

Due to the absence of carotenoids in the majority of infant formulae, the carotenoid status of neonates and toddlers is dependent on the mother's nutritional condition and also on infant feeding method. Increased mother $\mathrm{L} / \mathrm{Z}$ consumption during pregnancy was related with improved verbal intelligence and capacity to regulate behavior in midchildhood, indicating a possible advantage during prenatal development [179]. Many pregnant women take dietary supplements which in turn increases the plasma carotenoid levels [180]. The Norwegian Mother and Child Cohort Study (MoBa) revealed that the women who were not taking supplements has a lower plasma levels of carotenoids, i.e., $1.0 \pm 0.50 \mu \mathrm{mol} / \mathrm{L}$ as compared those who were taking dietary supplements [181].

\subsection{Role of Lutein and Zeaxanthin in Treatment of COVID-19}

COVID-19 severity is increased by oxidative stress and inflammation, particularly in the presence of chronic illnesses associated with the antioxidant system's fragility. As it develops, it causes hypoxemia, breathing difficulties, and acute respiratory distress syndrome. Some of these severe instances have high levels of pro-inflammatory cytokines (IL-6, IL2, IL7, IL10, GCSF, IP10, MCP1, MIP1, and TNF) and end in a deadly consequence [182]. NOX2-derived ROS, in particular, have been attributed to clotting and platelet activation, which either increases thrombin production and platelet aggregation or impairs arterial dilatation and endothelial dysfunction [183]. Carotenoids in diet are therefore known for 
quenching of ROS, like singlet oxygen and lipid peroxides, within the cell membrane's lipid bilayer. Some clear evidences indicated that high amounts of $\alpha$ - and $\beta$-carotene, lutein/zeaxanthin, and total carotenoids are strongly linked with reduced incidence of oxidative stress, inflammation, and vice versa [184].

\section{Lutein and Zeaxanthin Mediated Biological Pathways \\ 7.1. Antioxidative Pathway in Macula}

Since, the majority of lutein and zeaxanthin are present in human macula, here GSTP1 (glutathione S-transferase P1) and StARD3 (also known as steroidogenic acute regulatory domain 3 ) have been recognized as zeaxanthin and lutein binding proteins in human macula that allow the preferential accumulation of these carotenoids in humans. These proteins carry certain amino acid residues and loops that are matter of interest in binding with carotenoids (shown in Figure 5 for StARD3). However, the age-related decrease in the relationship between lutein and StARD3 could lead towards the primary cause of blindness in currently aging societies, which is age-related macular degeneration (AMD). This condition has two subtypes: wet AMD, which produces persistent vision damage despite therapeutic intrusions, and dry AMD, which has no particular treatment and causes progressive vision damage. Recently, Age-related Eye Disease (AREDS) and AREDS2 studies have undergone several clinical studies for preventive therapies. In this regard, AREDS2 has identified lutein as the carotenoid supplement to improve the positive impacts of the multi-vitamins and zinc, which appeared to be efficacious for the unique AREDS [185].

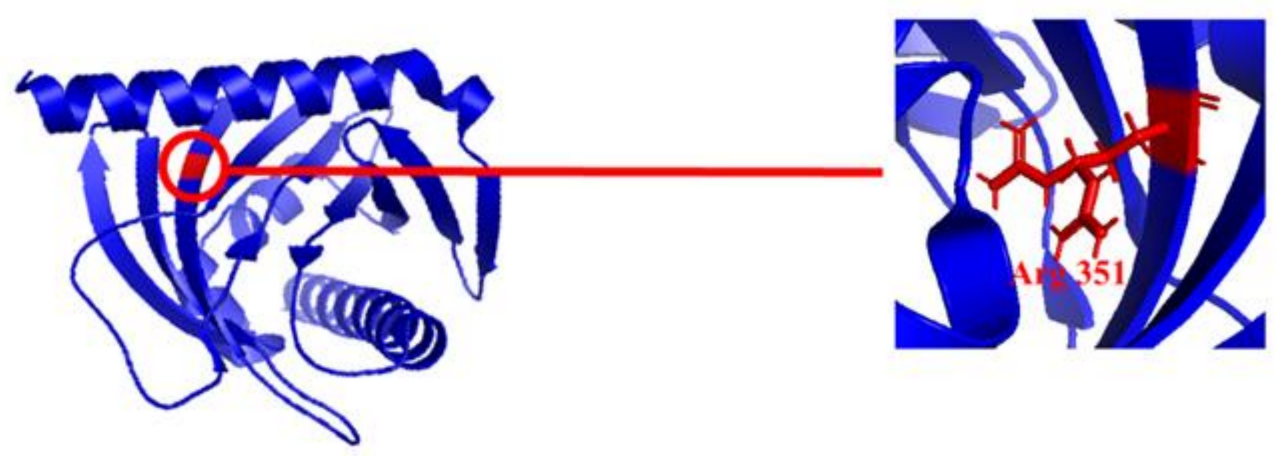

Figure 5. Computational Structure of StARD3 (PDB IB: 5I9J). Along with $\Omega$ loop, Arg 351 (shown in red sticks) is appeared to be an important amino acid residue involved in binding with lutein and allow the retention of lutein in human macula.

Exposure of retinal pigment epithelium (RPE) to disproportionate light energy has already been recounted to interrupt tight junctions. Light exposure also causes monocyte chemotactic protein-1 (MCP-1) synthesis, crucial for AMD due to its macrophage recruitment effects in the RPE and the choroid [186]. In this regard, Kamoshita et al. [187] have stated that lutein treatment encourages repair of photo-induced tight junction disruption in mice. Lutein lowers reactive oxygen species, enhances endogenous antioxidant dismutase (SOD) activity, and allows a continuous increase in sod1 and sod2 mRNA in the photo stressed RPE and neighboring choroid tissue. In addition, lutein reduces macrophagerelated induction of RPE-choroid tissue markers ( $\mathrm{f} 4 / 80$ and mcp-1). These results revealed that lutein supports tight junction repair and suppress inflammation in photo-stressed mice, lowering local oxidative stress through direct scavenging and, more preferably, through endogenous antioxidant enzymes inductions.

In addition to solar stressed conditions, Nuclear factor erythroid 2-related factor 2 (Nrf 2) signals get impaired in the aging RPE and thus become more prone to oxidative stress [188]. Transcription factor Nrf 2 regulates genes encode anti-oxidative and Phase II enzymes that are essential in cellular redox status maintenance and xenobiotic detoxification [189]. Under unconstrained conditions, Nrf 2 transcription activity is suppressed by the Kelch-like ECH associated protein 1(Keap1), resulting in the Nrf 2 proteasomal 
degradation. When the Nrf 2 pathway is activated, Nrf 2 translocates to the nucleus, creates a small musculoaponeurotic (Maf) fibrosarcoma heterodimer, and activates ARE-controlled genes [190]. The activation of Nrf 2 in human retinal pigment epithelial cell lines (ARPE-19 cells) is previously attributed to carotenoids like zeaxanthin and astaxanthin [191]. However, the role of lutein remains largely elusive in this activation. Recently, Frede et al. [192] have examined the effect of lutein on activation of nuclear factor erythroid 2 in ARPE-19 by lutein loaded Tween 40 micelles. Since micelles were nontoxic with a concentration of $\geq 0.04$ percent Tween 40 in APRE-19 cells, thus caused cellular lutein accumulation and were identified as a suitable delivery system. As a result, lutein considerably boosts Nrf 2 translocation in the nucleus by $1.5 \pm 0.4$ times compared to unloaded Lutein micelles. This work together shows that lutein does not only work as a direct antioxidant, but also active Nrf 2 in the cells of ARPE-19.

Similar to macular degeneration (AMD), proliferative retinopathy (DR) is also associated with an increased level of vascular endothelial growth factor (VEGF) in the eye, which ultimately results in increased development of new blood vessels through a phenomenon of neovascularization. For proliferative DR, pan-retinal photocoagulation therapy is considered to be the gold standard for treatment to preclude severe vision loss. However, the therapy has a damaging effect and leads to the loss of possible photoreceptors and evening vision [193]. For this purpose, Keegan et al. [194] have used an in vitro cell model of the retinal microvascular endothelium to determine the effect of certain drugs on neovascularization processes. Their findings illustrate that lutein and zeaxanthin diminish tube formation that VEGF triggers. These substances have the potential to block the neovascularization of VEGF in 5:1 ratio considerably. These carotenoids, individually or in combination, can reduce oxidative stress caused by VEGF induction and increase the activity of NADPH oxidase, Nox4 [195]. Furthermore, it appeared that Nox4 inhibitors could reduce the protective effect of $\mathrm{L}$ and $\mathrm{Z}$. These findings together demonstrate the protective role of $\mathrm{L}$ and $\mathrm{Z}$ in reducing VEGF-mediated neovascularization via a Nox4-dependent pathway.

\section{Role of Human Macular Carotenoids in Reducing Alu RNA during Dry AMD}

The dysfunction of the miRNA-processing enzyme, DICER1, and the accumulation of Alu RNA are associated with the pathogenesis of dry AMD. This finding is unique for dry AMD, since DICER1 levels in the RPE of human donor eyes and other retinal disorders like vitelliform macular dystrophy, retinitis pigmentosa, and retinal detachment, was not reduced [196]. There exists mounting evidence regarding the role of cellular oxidative processes in disease progression. Hydrogen peroxide $\left(\mathrm{H}_{2} \mathrm{O}_{2}\right)$ is regarded as one of the powerful oxidants in ocular tissues [197]. In vitro studies have demonstrated that $\mathrm{H}_{2} \mathrm{O}_{2}$ exposure causes apoptosis and decreases cell viability in RPE [198]. Notably, $\mathrm{H}_{2} \mathrm{O}_{2}$ has been found to downregulate DICER1 mRNA in human RPE cells. Chong et al. [199] showed that lutein, but not zeaxanthin, had the potential to diminish the cytotoxic impact of $\mathrm{H}_{2} \mathrm{O}_{2}$ and the accumulation of Alu RNA in $\mathrm{H}_{2} \mathrm{O}_{2}$ challenged cells. However, before $\mathrm{H}_{2} \mathrm{O}_{2}$ exposure, when $\mathrm{L}$ was used alone or in conjunction with $\mathrm{Z}$ pre-treatment, it dramatically increased ARPE-19 cell survival and decreased Alu RNA levels in contrast to the negative control. In summary, these findings reveal a previously unknown role of $\mathrm{H}_{2} \mathrm{O}_{2}$ in the etiology of AMD and establish a foundation for further investigation of LUT and ZEA for preventing Alu RNA toxicity in RPE.

\subsection{Zeaxanthin Mediated Apoptosis via ROS-Regulated Signaling Pathway in Human Gastric Cancer Cells}

Gastric cancer is a significant public health issue and is categorized among the frequently occurring malignancies of the digestive system. Cancerous cells' survival, differentiation, and migration are typically mediated by distinct intracellular signaling pathways, like the MAPK and AKT pathways. Members of the mitogen-activated protein kinase (MAPK) family, such as extracellular signal-regulated protein kinase (ERK), c-Jun $\mathrm{N}$-terminal protein kinase (JNK), and p38 MAPK, are required for cell survival [200]. AKT is a serine/threonine protein kinase that may phosphorylate various proteins and is re- 
quired for cell endurance. Research has demonstrated that the AKT and MAPK signaling pathways block the STAT3 signaling pathway [201].

Additionally, mitochondria create reactive oxygen species (ROS), i.e., superoxide anions, hydrogen peroxide, and hydroxyl radicals for signaling intermediates [202]. The formation of reactive oxygen species (ROS) is indeed one of the methods through which tumor cells are killed. Zeaxanthin signal transduction pathways play a critical role in generating reactive oxygen species (ROS) in the human gastric cancer cells [203]. Because control of intracellular ROS is critical for apoptosis, increased amounts of ROS inside the cell can trigger apoptosis via the MAPK pathway [204]. Previous research has established that although zeaxanthin can inhibit the development of reactive oxygen species (ROS) in normal cells, it can also promote ROS generation in melanoma [205]. In this regard, Sheng et al. [203] demonstrated that zeaxanthin induces apoptosis by lowering the mitochondrial membrane potential and increasing the expression of Cytochrome C, Bax, cleaved-caspase-3 (clecas-3), and cleaved-PARP (cle-PARP) while decreasing the expression of Bcl-2, pro-caspase-3 (pro-cas-3), and pro-PARP. Furthermore, zeaxanthin induced G2/M phase arrest by raising p21 and p27 levels and decreasing AKT, Cyclin A, Cyclin B1, and Cyclin-dependent kinase 1/2 (CDK1/2) levels. Nevertheless, both ROS scavenger $\mathrm{N}$-acetylcysteine (NAC) and MAPK inhibitors prevented zeaxanthin-induced apoptosis, and MAPK regulated NF-B and STAT3 signaling pathway by decreasing their protein expression levels in the presence of zeaxanthin.

\section{Industrial Applications of Lutein and Zeaxanthin}

Despite having oncogenic, immunosuppressive, and non-eco-friendly properties, industrialization has accelerated the development and widespread usage of synthetic colorants in various fields of life. However, microbial pigments are gaining interest compared to synthetic colors because of their greater output, ease of downstream processing, and longer shelf life [206]. Although the recent market share of carotenoids is unknown, numerous market research surveys have indicated a definite upward tendency in the carotenoid industry. According to a BBC study, the global carotenoid industry-valued $\$ 1.5$ billion in 2017 and is projected to reach $\$ 2.0$ billion by 2022 [207]. Approximately $60 \%$ of the overall market share for carotenoids is comprised of $\beta$-carotene, astaxanthin, and lutein [208]. The following are the industrial uses of lutein and zeaxanthin:

\subsection{Textile Industry}

Among other industries, textile is the primary user of diverse dyestuffs. According to Lebeau et al. [209], the global dyestuff business demands a more significant proportion of natural pigments, which has resulted in the creation of natural colorants from plants and microorganisms. Natural colors derived from fungus have been demonstrated to be the best substitute of synthetic pigments due to their prompt development, ease of processing, and critical roles in transcription and intercellular communication. By extracting natural colorants from Cassia tora seeds, Eucalyptus sp. and Grewia optiva leaves in an aqueous media under various conditions, Dayal and Dobhal [210] have imparted their shades to silk, cotton, and jute textiles. Recently, it has been discovered that the blooms of Tecoma stans contain a fast-color yellow pigment called zeaxanthin. However, the main limitation of using plant-based dyes in today's textile industry involves maintaining the color strength and fastness of fabrics dyed with natural colorants. In this regard, Adeel et al. [211] showed that $30 \mathrm{kGy}$ gamma-ray treatment could increase the color intensity and fastness of lutein isolated from Marigold (Tagetes erecta L.) flowers. These findings indicate that gamma ray-induced lutein extraction from marigold flowers can work as a natural dye to generate yellowish-green shades.

\subsection{Feed Industry}

The natural pigmentation of poultry (particularly broilers) is mainly influenced by their diet's composition, particularly by the carotenoid content. Lutein is currently commer- 
cialized globally as a feed supplement for poultry [212]. Commercially, marigold flower extract is added to poultry feed to enhance the pigmentation of birds (fat and skin) and egg yolks [213]. Additionally, partial cleavage (40-60\%) of esterified pigments may occur within the broiler's stomach [214]. Saponification is typically conducted during commercial preparations to increase the extract's pigmentation value. Once ingested, free (unesterified) lutein is transported and stored as diesterified lutein in the liver or integumentary tissues [215]. The consumer frequently associates a brilliant yellow color in egg yolks, skins, and fatty tissues with excellent health and premium quality. Moreover, feeding lutein may increase the production performance of yellow catfish and the reproductive performance of quail [216]. Additionally, zeaxanthin is utilized in the food sector as a feed additive and colorant for birds, pigs, and fish. The pigment gives birds' skin and egg yolks a yellowish color, while it is used for skin pigmentation in pigs and fish [217].

\subsection{Cosmetics Industry}

By successfully decreasing the quantity of oxidative stress in the skin, topical application of lutein unintentionally aids in moisture retention and anti-aging effects [218]. Marigold flower extract (Tagetes erecta) is primarily used to produce a brand of lutein called FloraGLO ${ }^{\circledR}$ lutein, which is marketed by Kemin industries. FloraGLO ${ }^{\circledR}$ lutein could be taken orally or applied topically. Ten milligrammes of FloraGLO ${ }^{\circledR}$ lutein daily improves skin elasticity, hydration, and lipid content [219]. However, the chemical processes behind the positive effects of xanthophylls (lutein/zeaxanthin) on the skin remain unclear. But, Li et al. [121] have recently demonstrated that lutein and zeaxanthin modify gene expression by stimulating hyaluronan synthesis in a human keratinocyte model. As a result, these modifications provide a mechanistic basis for the clinical benefits of xanthophylls.

\section{Future Perspective}

The global nutraceutical market is projected to extensive growth due to an increased demand for healthy and organic food supplements. It has been noted that the amount of zeaxanthin and lutein in supplements should be balanced to successfully increase macular pigment optical density and effectivity of antioxidant pathways. The everlasting effects of $\mathrm{L}$ and $\mathrm{Z}$ status in reducing the menace for age-related and other maladies can be apprehended in long-term epidemiological studies. Numerous approaches are currently on their way, but the actual pooling of statistics from accessible cohorts can promote investigations to the degree where phenotypes and genotypes may alter $\mathrm{L}$ and $\mathrm{Z}$ levels in dietary supplements for optimal benefits over a wide range of intake levels.

Although various natural sources are available for lutein and zeaxanthin production, the need of an hour is to instigate industrial involvement in research and development activities for bacterial lutein and zeaxanthin production and other value-added bio-products, using a bio-refinery approach. For more than a century, it has been speculated that isoprenoid pathways are the most palpable targets for the laboratory evolution of xanthophylls. Most laboratory-evolved and engineered isoprenoid pathways have so far accumulated unique carotenoids as a component of complicated assortments. This may be adequate for the discovery of new carotenoids. Still, to provide valuable insights for a synthetic route to a specific compound, the pathway must be further engineered to become more precise. Usually, the natural carotenoid pathway tends to produce only a few end products that probably follow a similar course of "pruning." Several possible approaches, including the engineering of carotenoid biosynthesis module that mainly include the choice and engineering of unique enzymes, localized expression of key enzymes, optimization of gene expression and enhancing the carotenoid stowage in producing cells, have been enlisted to transform nonspecific pathways into the ones that upsurge the metabolic flux in the direction of target production, i.e., lutein and zeaxanthin. However, still, an in silico metagenomics approach needs to be underpinned for this purpose. In this regard, omics analysis entails the valuable means to comprehend the whole cell activity and can further expand carotenoid production. 
A comparative proteomic examination of excessive lutein and zeaxanthin producing strains [220] and transcriptomic analysis of a lycopene strain using fructose as carbon source [221] acknowledge synchronized pathways and genes that can be additionally improved for carotenoid synthesis. Moreover, lutein and zeaxanthin synthesis pathway may engineer possibly after the accumulation of neutral mutations (in the context of the desired pathway). In this regard, a number of genetically engineered microbial strains are widely used in industrial processes for enhanced lutein and zeaxanthin production. But pronounced attempts are required for microbial carotenoid over production since, the genetic stability of microbial strains limits their applications in industry. Only a few bioprocesses that emphasis on chromosomal change address such limitations but most of them still use plasmids for gene regulation that are less stable and require antibiotics which tolerate higher metabolic burden [222]. Therefore, a number of policies have been employed to unravel these problems in which novel marker-free genetic integration tools based on the CRISPR-Cas system are the matter of interest. Although the production of zeaxanthin is enhanced through this aforementioned tool but lutein production needs to be enhanced through this technique too.

Moreover, C35, C45, and C50 carotenoid pathways discovered in laboratories allow sophisticated experimental efficiencies for validating the production of lutein and zeaxanthin. In this regard, investigations directed at evolving pathway specificity in the laboratory would permit researchers to track the effect of each genetic change on the esterification and synthesis of lutein and zeaxanthin. More research focused on the use of agro-industrial wastes, high lutein, and zeaxanthin producing organisms through metabolic engineering strategies, bioreactor design and control strategies for microbial carotenoids production is necessary to cover the worldwide demand of lutein and zeaxanthin for poultry, cosmetic, food, feed, beverages and others industries.

\section{Conclusions}

Lutein and zeaxanthin are the typical xanthophylls that improve food quality due to their high abundance in five kingdoms of life with major availability in Kingdom Plantae and Protista. Although marigold flower and certain eubacterial strains meet the global demand for lutein and zeaxanthin to some extent, there is still a huge opportunity to contribute to the global demand for natural lutein and zeaxanthin. For this purpose, a number genetic engineering techniques including random mutagenesis and gene assembly and CRISPR/Cas9 based approaches have been employed to enhance the productivity of lutein and zeaxanthin but a metagenomics approach needs to be implied for the pronounced applications. Numerous investigations, both preclinical and clinical, have indicated that lutein and zeaxanthin can slow the course of retroviral, malignant, and ocular disorders, mostly by quenching free radicals and protecting them from oxidative damage. According to study findings, lutein and zeaxanthin can effectively mitigate oxidative stress in vivo and protect the eye. Additionally, due to their beneficial bioactive characteristics, the concept of integrating lutein and zeaxanthin into meals, nutraceuticals, or cosmetic is gaining attraction.

Author Contributions: All authors have made a substantial contribution to the review. J.Z., A.A., F.I.S., N.E. and U.F.G. conceptualized the topic and the manuscript structure, M.A.M., D.F., C.C., R.C. and M.I. contributed to the drafting, writing and preparation of the original and final draft. All authors have read and agreed to the published version of the manuscript.

Funding: This research received no external funding.

Institutional Review Board Statement: Not applicable.

Informed Consent Statement: Not applicable.

Data Availability Statement: Not applicable. 
Conflicts of Interest: The authors desire to endorse that there is no recognized conflict of interest allied with this publication and there has been no substantial economic funding for this work that could have predisposed its consequence.

\section{References}

1. Arunkumar, R.; Gorusupudi, A.; Bernstein, P.S. The macular carotenoids: A biochemical overview. Biochim. Biophys. Acta Mol. Cell Biol. Lipids 2020, 1865, 158617. [CrossRef] [PubMed]

2. Takaichi, S. Carotenoids in algae: Distributions, biosyntheses and functions. Mar. Drugs 2011, 9, 1101-1118. [CrossRef] [PubMed]

3. Li, M.; Gan, Z.; Cui, Y.; Shi, C.; Shi, X. Structure and function characterization of the phytoene desaturase related to the lutein biosynthesis in Chlorella protothecoides CS-41. Mol. Biol. Rep. 2012, 40, 3351-3361. [CrossRef]

4. Bernstein, P.S.; Li, B.; Vachali, P.P.; Gorusupudi, A.; Shyam, R.; Henriksen, B.S.; Nolan, J.M. Lutein, zeaxanthin, and mesozeaxanthin: The basic and clinical science underlying carotenoid-based nutritional interventions against ocular disease. Prog. Retin. Eye Res. 2016, 50, 34-66. [CrossRef]

5. Granado, F.; Olmedilla, B.; Blanco, I. Nutritional and clinical relevance of lutein in human health. Br. J. Nutr. 2003, 90, 487-502. [CrossRef]

6. Li, B.; George, E.W.; Rognon, G.T.; Gorusupudi, A.; Ranganathan, A.; Chang, F.Y.; Bernstein, P.S. Imaging lutein and zeaxanthin in the human retina with confocal resonance Raman microscopy. Proc. Nat. Acad. Sci. USA 2020, 117, 12352-12358. [CrossRef] [PubMed]

7. Evans, M.; Beck, M.; Elliott, J.; Etheve, S.; Roberts, R.; Schalch, W. Effects of formulation on the bioavailability of lutein and zeaxanthin: A randomized, double-blind, cross-over, comparative, single-dose study in healthy subjects. Europ. J. Nutri. 2013, 52, 1381-1391. [CrossRef] [PubMed]

8. Maoka, T. Recent progress in structural studies of carotenoids in animals and plants. Arch. Biochem. Biophys. 2009, 483, 191-195. [CrossRef] [PubMed]

9. Renzi, L.M.; Bovier, E.R.; Hammond, B.R. A role for the macular carotenoids in visual motor response. Nutr. Neurosci. 2013, 16, 262-268. [CrossRef] [PubMed]

10. Landrum, J.T.; Bone, R.A. Lutein, zeaxanthin, and the macular pigment. Arch. Biochem. Biophys. 2001, 385, 28-40. [CrossRef] [PubMed]

11. The Global Market for Carotenoids. BCC Research. 2018. Retrieved 28 October 2018. Available online: https://www.bccresearch. $\mathrm{com} /$ market-research/food-and-beverage/carotenoids-market-fod025c.html (accessed on 5 September 2021).

12. Cordero, B.F.; Obraztsova, I.; Couso, I.; Leon, R.; Vargas, M.A.; Rodriguez, H. Enhancement of lutein production in Chlorella sorokiniana (Chorophyta) by improvement of culture conditions and random mutagenesis. Mar. Drugs 2011, 9, 1607-1624. [CrossRef] [PubMed]

13. Marino, T.; Casella, P.; Sangiorgio, P.; Verardi, A.; Ferraro, A.; Hristoforou, E.; Molino, A.; Musmarra, D. Natural beta-carotene: A microalgae derivate for nutraceutical applications. Chem. Eng. Trans. 2020, 79, 103-108.

14. Zeaxanthin Market. Transparency Market Research. 2020. Available online: https://www.transparencymarketresearch.com/ zeaxanthin-market (accessed on 5 September 2021).

15. Qv, X.V.; Zeng, Z.P.; Jiang, J.G. Preparation of lutein microencapsulation by complex coacervation method and its physicochemical properties and stability. Food Hydrocoll. 2011, 25, 1596-1603. [CrossRef]

16. Gouveia, L.; Empis, J. Relative stabilities of microalgal carotenoids in microalgal extracts, biomass and fish feed: Effect of storage conditions. Innov. Food Sci. Emerg. Technol. 2003, 4, 227-233. [CrossRef]

17. Hirschberg, J. Carotenoid biosynthesis in flowering plants. Curr. Opin. Plant Biol. 2001, 4, 210-218. [CrossRef]

18. Concepcion, R.M.; Boronat, A. Elucidation of the methylerythritol phosphate pathway for isoprenoid biosynthesis in bacteria and plastids. A metabolic milestone achieved through genomics. Plant physiology 2002, 130, 1079-1089. [CrossRef]

19. Rohmer, M.; Knani, M.; Simonin, P.; Sutter, B.; Sahm, H. Isoprenoid biosynthesis in bacteria: A novel pathway for the early steps leading to isopentenyl diphosphate. Biochem. J. 1993, 295, 517-524. [CrossRef]

20. Cunningham, F.X.; Lafond, T.P., Jr.; Gantt, E. Evidence of a role for LytB in the nonmevalonate pathway of isoprenoid biosynthesis. J. Bacteriol. 2000, 182, 5841-5848. [CrossRef]

21. Arigoni, D.; Eisenreich, W.; Latzel, C.; Sagner, S.; Radykewicz, T.; Zenk, M.H.; Bacher, A. Dimethylallyl pyrophosphate is not the committed precursor of isopentenyl pyrophosphate during terpenoid biosynthesis from 1-deoxyxylulose in higher plants. Proc. Nat. Acad. Sci. USA 1999, 96, 1309-1314. [CrossRef]

22. Jahns, P.; Holzwarth, A.R. The role of the xanthophyll cycle and of lutein in photoprotection of photosystem II. Biochim. Biophys. Acta 2012, 1817, 182-193. [CrossRef] [PubMed]

23. Cunningham, F.X.; Pogson, B.; Sun, Z.; McDonald, Z.; DellaPenna, K.A.; Gantt, E. Functional Analysis of the $\beta$ and $\varepsilon$ Lycopene Cyclase Enzymes of Arabidopsis Reveals a Mechanism for Control of Cyclic Carotenoid Formation. Plant Cell 1996, 8, 1613-1626. [CrossRef]

24. Bialek-Bylka, G.; Sakano, Y.; Mizoguchi, T.; Shimamura, T.; Phillip, D.; Koyama, Y.; Young, A. Central-Cis isomers of lutein found in the major light-harvesting complex of Photosystem II (LHC Ilb) of higher plants. Photosynth. Res. 2004, 56, 255-264. [CrossRef]

25. Tian, L.; DellaPenna, D. Progress in understanding the origin and functions of carotenoid hydroxylases in plants. Arch. Biochem. Biophys. 2004, 430, 22-29. [CrossRef] 
26. Kim, J.; DellaPenna, D. Defining the primary route for lutein synthesis in plants: The role of Arabidopsis carotenoid beta-ring hydroxylase CYP97A3. Proc. Nat. Acad. Sci. USA 2006, 103, 3474-3479. [CrossRef] [PubMed]

27. Havaux, M.; García-Plazaola, J.I. Beyond non-photochemical fluorescence quenching: The overlapping antioxidant functions of zeaxanthin and tocopherols. In Non-Photochemical Quenching and Energy Dissipation in Plants, Algae and Cyanobacteria (Advances in Photosynthesis and Respiration); Demmig-Adams, B., Garab, G., Adams, W.W., III, Govindjee, Eds.; Springer: Dordrecht, The Netherlands, 2014; Volume 40, pp. 583-603.

28. Calvo, M.M. Lutein: A valuable ingredient of fruit and vegetables. Crit. Rev. Food Sci. Nutr. 2005, 45, 671-696. [CrossRef] [PubMed]

29. Sommerburg, O.; Keunen, J.E.; Bird, A.C.; van Kuijk, F.J. Fruits and vegetables that are sources for lutein and zeaxanthin: The macular pigment in human eyes. Br. J. Ophthalmol. 1998, 82, 907-910. [CrossRef]

30. Humphries, J.M.; Khachik, F. Distribution of Lutein, Zeaxanthin, and Related Geometrical Isomers in Fruit, Vegetables, Wheat, and Pasta Products. J. Agric. Food Chem. 2003, 51, 1322-1327. [CrossRef]

31. Harashima, K.; Ohno, T.; Sawachika, T.; Hidaka, T.; Ohnishi, E. Carotenoids in orange pupae of the swallowtail, Papilio xuthus. Insect Biochem. 1972, 2, 29-48. [CrossRef]

32. Maoka, T.; Kawase, N.; Hironaka, M.; Nishida, R. Carotenoids of hemipteran insects, from the perspective of chemo-systematic and chemical ecological studies. Biochem. Sys. Ecol. 2021, 95, 104241. [CrossRef]

33. Czeczuga, B. The presence of carotenoids in various species of Lepidoptera. Biochem. Sys. Ecol. 1986, 14, 345-351. [CrossRef]

34. Asahina, S. The development of odonatology in the Far Esast. Odonatologica 1974, 3, 5-12.

35. Maoka, T.; Kawase, N.; Ueda, T.; Nishida, R. Carotenoids of dragonflies, from the perspective of comparative biochemical and chemical ecological studies. Biochem. Sys. Ecol. 2020, 89, 104001. [CrossRef]

36. Fernández-Cano, M.I.; Arreciado Maramon, A.; Feijoo-Cid, M. The Bachelor's thesis in nursing: Characteristics and students' approach and satisfaction. Nurs Educ Pract. 2021, 53, 103067. [CrossRef]

37. Perry, A.; Rasmussen, H.; Johnson, E. Xanthophyll (lutein, zeaxanthin) content in fruits, vegetables and corn and egg products. J. Food Comp. Anal. 2009, 22, 9-15. [CrossRef]

38. García-Herrera, P.; Sánchez-Mata, M.C.; Cámara, M.; Tardío, J.; Olmedilla-Alonso, B. Carotenoid content of wild edible young shoots traditionally consumed in Spain (Asparagus acutifolius L., Humulus lupulus L., Bryonia dioica Jacq. and Tamus communis L.). J. Sci. Food Agric. 2014, 94, 1914-1916. [CrossRef]

39. De Sá, M.C.; Rodriguez-Amaya, D.B. Carotenoid composition of cooked green vegetables from restaurants. Food Chemistry 2003, 83, 595-600. [CrossRef]

40. US Department of Agriculture, Agricultral Research Service, Nutrient Data Laboratory USDA National Nutrient Database for Standard Reference. Available online: http:/ / www.ars.usda.gov/ba/bhnrc/ndl (accessed on 15 March 2016).

41. Lakshminarayana, R.; Raju, M.; Krishnakantha, T.P.; Baskaran, V. Lutein and zeaxanthin in leafy greens and their bioavailability: Olive oil influences the absorption of dietary lutein and its accumulation in adult rats. J. Agric. Food Chem. 2007, 55, 6395-6400. [CrossRef] [PubMed]

42. Bangera, M.; Sangeetha, R.K.; Vallikannan, B. Provitamin-A and xanthophyll carotenoids in vegetables and food grains of nutritional and medicinal importance. Int. J. Food Sci. Technol. 2011, 46, 315-323. [CrossRef]

43. Aruna, G.; Baskaran, V. Comparative study on the levels of carotenoids lutein, zeaxanthin and $\beta$-carotene in Indian spices of nutritional and medicinal importance. Food Chem. 2010, 123, 404-409. [CrossRef]

44. Fernandez-Orozco, R.; Gallardo-Guerrero, L.; Hornero-Méndez, D. Carotenoid profiling in tubers of different potato (Solanum sp) cultivars: Accumulation of carotenoids mediated by xanthophyll esterification. Food Chem. 2013, 141, 2864-2872. [CrossRef]

45. Meléndez-Martínez, A.J.; Mapelli-Brahm, P.; Hornero-Méndez, D.; Vicario, I.M. Chapter 1: Structures, Nomenclature and General chemistry of carotenoids and their esters. In Food Chemistry, Function and Analysis; Mercadante, A.Z., Ed.; Royal Society of Chemistry: London, UK, 2019; pp. 3-50.

46. Kopsell, D.; Curran-Celentano, J. Carotenoid and Chlorophyll Pigments in Sweet Basil Grown in the Field and Greenhouse. Hortscience 2005, 40, 1230-1233. [CrossRef]

47. Daly, T.; Jiwan, M.A.; O'Brien, N.M.; Aherne, S.A. Carotenoid content of commonly consumed herbs and assessment of their bioaccessibility using an in vitro digestion model. Plant Foods Hum. Nutr. 2010, 65, 164-169. [CrossRef]

48. Eisenhauer, B.; Natoli, S.; Liew, G.; Flood, V.M. Lutein and Zeaxanthin Food Sources, Bioavailability and Dietary Variety in Age-Related Macular Degeneration Protection. Nutrients 2017, 9, 120. [CrossRef]

49. Singh, G.; Kawatra, A.; Sehgal, S. Nutritional composition of selected green leafy vegetables, herbs and carrots. Plant Foods Hum Nutr. 2001, 56, 359-364. [CrossRef]

50. Aruna, G.; Bangera, M.; Baskaran, V. Lutein content of selected Indian vegetables and vegetable oils determined by HPLC. J. Food Compos. Anal. 2009, 22, 632-636. [CrossRef]

51. Khonsarn, N.; Lawan, S. Level of Xanthophyll, Lutein and Zeaxanthin in Selected Thai Fruits Determined by HPLC. IPCBEE 2012, 39, 240.

52. Updike, A.A.; Schwartz, S.J. Thermal processing of vegetables increases cis isomers of lutein and zeaxantin. J. Agric. Food Chem. 2003, 51, 6184-6190. [CrossRef] [PubMed]

53. Rios, S.; Dias Paes, M.C.; Cardoso, W.S.; Borém, A.; Teixeira, F.F. Color of Corn Grains and Carotenoid Profile of Importance for Human Health. Am. J. Plant Sci. 2014, 5, 857-862. [CrossRef] 
54. Abdel-Aal, E.S.M.; Young, J.C.; Rabalski, I.; Hucl, P.; Frégeau Reid, J. Identification and Quantification of Seed Carotenoids in Selected Wheat Species. J. Agr. Food Chem. 2007, 55, 787-794. [CrossRef] [PubMed]

55. Hentschel, V.; Kranl, K.; Hollmann, J.; Lindhauer, M.G.; Böhm, V.; Bitsch, R. Spectrophotometric determination of yellow pigment content and evaluation of carotenoids by high-performance liquid chromatography in durum wheat grain. J. Agric. Food Chem. 2002, 50, 6663-6668. [CrossRef]

56. Del Campo, J.A.; Moreno, J.; Rodríguez, H.; Vargas, M.A.; Rivas, J.; Guerrero, M.G. Carotenoid content of chlorophycean microalgae: Factors determining lutein accumulation in Muriellopsis sp. (Chlorophyta). J. Biotechnol. 2000, 76, 51-59. [CrossRef]

57. Saha, S.H.; Murray, P.; Ermis, H. Marine Microalgae for Potential Lutein Production. Appl. Sci. 2020, 10, 6457. [CrossRef]

58. Ho, S.H.; Chan, M.C.; Liu, C.C.; Chen, C.Y.; Lee, W.L.; Lee, D.J.; Chang, J.S. Enhancing lutein productivity of an indigenous microalga Scenedesmus obliquus FSP-3 using light-related strategies. Bioresour. Technol. 2014, 152, 275-282. [CrossRef] [PubMed]

59. Takaichi, S.; Yokoyama, A.; Mochimaru, M.; Uchida, H.; Murakami, A. Carotenogenesis diversification in phylogenetic lineages of Rhodophyta. J. Phycol. 2016, 52, 329-338. [CrossRef]

60. Deli, J.; Gonda, S.; Nagy, L.Z.; Szabó, I.; Gulyás-Fekete, G.; Agócs, A.; Vasas, G. Carotenoid composition of three bloom-forming algae species. Food Res. Int. 2014, 65, 215-223. [CrossRef]

61. García-González, M.; Moreno, J.; Manzano, J.C.; Florêncio, F.J.; Guerrero, M.G. Production of Dunaliella salina biomass rich in 9-cis- $\beta$-carotene and lutein in a closed tubular photobioreactor. J. Biotechnol. 2005, 115, 81-90. [CrossRef]

62. El-Baky, H.A.; El Baz, F.K.; El-Baroty, G.S. Production of carotenoids from marine microalgae and its evaluation as safe food colorant and lowering cholesterol agents. Amer. Eur. J. Agric. Environ. Sci. 2007, 2, 792-800.

63. Inbaraj, B.S.; Chien, J.T.; Chen, B.H. Improved high performance liquid chromatographic method for determination of carotenoids in the microalga Chlorella pyrenoidosa. J. Chromatogr. A 2006, 1102, 193-199. [CrossRef]

64. Minhas, A.K.; Hodgson, P.; Barrow, C.J.; Sashidhar, B.; Adholeya, A. The isolation and identification of new microalgal strains producing oil and carotenoid simultaneously with biofuel potential. Bioresour. Technol. 2016, 211, 556-565. [CrossRef] [PubMed]

65. Gayathri, S.; Rajasree, S.R.R.; Suman, T.Y.; Aranganathan, L.; Thriuganasambandam, R.; Narendrakumar, G. Induction of $\beta$, $\varepsilon$-carotene-3, 3'-diol (lutein) production in green algae Chlorella salina with airlift photobioreactor: Interaction of different aeration and light-related strategies. Biomass Convers. Biorefin. 2020, 11, 2003-2011. [CrossRef]

66. Huang, W.; Lin, Y.; He, M.; Gong, Y.; Huang, J. Induced High-Yield Production of Zeaxanthin, Lutein, and $\beta$-Carotene by a Mutant of Chlorella zofingiensis. J. Agric. Food Chem. 2018, 66, 891-897. [CrossRef]

67. Del Campo, J.A.; Rodríguez, H.; Moreno, J.; Vargas, M.Á.; Rivas, J.; Guerrero, M.G. Accumulation of astaxanthin and lutein in Chlorella zofingiensis (Chlorophyta). Appl. Microbiol. Biotechnol. 2004, 64, 848-854. [CrossRef] [PubMed]

68. Zia-Ul-Haq, M. Historical and introductory aspects of carotenoids. In Carotenoids: Structure and Function in the Human Body; Zia-Ul-Haq, M., Dewanjee, S., Riaz, M., Eds.; Springer: Cham, Switzerland, 2021; pp. 1-42.

69. Jin, E.; Feth, B.; Melis, A. A mutant of the green alga Dunaliella salina constitutively accumulates zeaxanthin under all growth conditions. Biotechnol. Bioeng. 2003, 81, 115-124. [CrossRef]

70. Shi, X.; Zhang, X.; Chen, F. Heterotrophic production of biomass and lutein by Chlorella protothecoides on various nitrogen sources. Enzyme Microb. Technol. 2000, 27, 312-318. [CrossRef]

71. Piña, F; Contreras-Porcia, L. Enhancement of Xanthophyll Synthesis in Porphyra/Pyropia Species (Rhodophyta, Bangiales) by Controlled Abiotic Factors: A Systematic Review and Meta-Analysis. Mar. Drugs 2021, 19, 221. [CrossRef]

72. Koizumi, J.; Takatani, N.; Kobayashi, N.; Mikami, K.; Miyashita, K.; Yamano, Y.; Wada, A.; Maoka, T.; Hosokawa, M. Carotenoid Profiling of a Red Seaweed Pyropia yezoensis: Insights into Biosynthetic Pathways in the Order Bangiales. Mar. Drugs 2018, 16, 426. [CrossRef]

73. Oh, S.; Lee, E.; Choe, E. Light Effects on Lipid Oxidation, Antioxidants, and Pigments in Dried Laver (Porphyra) during Storage. Food Sci. Biotechnol. 2014, 23, 701-709. [CrossRef]

74. Esteban, R.; Martínez, B.; Fernández-Marín, B.; Becerril, J.M.; García-Plazaola, J.I. Carotenoid composition in Rhodophyta: Insights into xanthophyll regulation in Corallina elongata. Eur. Jol. Phycol. 2009, 44, 221-230. [CrossRef]

75. Zia-Ul-Haq, M. Past, present and future of Carotenoids Research. In Carotenoids: Structure and Function in the Human Body; Zia-Ul-Haq, M., Dewanjee, S., Riaz, M., Eds.; Springer: Cham, Switzerland, 2021; pp. 827-854.

76. Goodwin, T.W.; Jamikorn, M. Studies in Carotenogenesis. Some Observations on Carotenoid Synthesis in Two Varieties of Euglena gracilis. J. Protozool. Res. 1954, 1, 216-219. [CrossRef]

77. Manikprabhu, D.; Lingappa, K. $\gamma$ Actinorhodin a natural and attorney source for the synthetic dye to detect acid production of fungi. Saudi J. Biol. Sci. 2013, 20, 163-168. [CrossRef] [PubMed]

78. Venil, C.K.; Velmurugan, P.; Dufossé, L.; Devi, P.R.; Ravi, A.V. Fungal Pigments: Potential Coloring Compounds for Wide Ranging Applications in Textile Dyeing. J. Fungi 2020, 6, 68. [CrossRef]

79. Dufosse, L. Microbial production of food grade pigments. Food Technol. Biotechnol. 2006, 44, 313-321.

80. Mohamed, H.; El-Shanawany, A.R.; Shah, A.M.; Nazir, Y.; Naz, T.; Ullah, S.; Song, Y. Comparative Analysis of Different Isolated Oleaginous Mucoromycota Fungi for Their $\gamma$-Linolenic Acid and Carotenoid Production. BioMed. Res. Int 2020, $2020,1-13$. [CrossRef]

81. Rodríguez-Sáiz, M.; de la Fuente, J.L.; Barredo, J.L. Metabolic engineering of Mucor circinelloides for zeaxanthin production. Methods Mol. Bio. (Clifton, N.J.) 2012, 898, 133-151. [CrossRef] 
82. Vila, E.; Hornero-Méndez, D.; Azziz, G.; Lareo, C.; Saravia, V. Carotenoids from heterotrophic bacteria isolated from Fildes Peninsula, King George Island. Antarctica. Biotechnol. Rep. 2019, 21, e00306. [CrossRef]

83. Stankovic, I. Zeaxanthin. Chemical and Technical Assessment (CTA), 63rd ed.; Food and Agriculture Organization of the United Nations: Rome, Italy, 2004.

84. Gierhart, D.L. Production of Zeaxanthin and Zeaxanthin-Containing Compositions. Applied Food Biotechnology, Inc. US Patent 5308759A, 3 May 1994.

85. Choi, S.K.; Osawa, A.; Maoka, T.; Hattan, J.; Ito, K.; Uchiyama, A.; Suzuki, M.; Shindo, K.; Misawa, N. 3- $\beta-$ Glucosyl-3'- $\beta-$ quinovosyl zeaxanthin, a novel carotenoid glycoside synthesized by Escherichia coli cells expressing the Pantoea ananatis carotenoid biosynthesis gene cluster. Appl. Microbiol. Biotechnol. 2013, 97, 8479-8486. [CrossRef]

86. Fidan, O.; Zhan, J. Discovery and engineering of an endophytic Pseudomonas strain from Taxus chinensis for efficient production of zeaxanthin diglucoside. J. Biol. Eng. 2019, 13, 66. [CrossRef]

87. Vila, E.; Hornero-Méndez, D.; Lareo, C.; Saravia, V. Biotechnological production of zeaxanthin by an Antarctic Flavobacterium: Evaluation of culture conditions. J. Biotechnol. 2020, 319, 54-60. [CrossRef] [PubMed]

88. Bhosale, P.; Bernstein, P.S. Beta-carotene production by Flavobacterium multivorum in the presence of inorganic salts and urea. J. Ind. Microbiol. Biotechnol. 2004, 31, 565-571. [CrossRef]

89. Bhosale, P.; Larson, A.J.; Bernstein, P.S. Factorial analysis of tricarboxylic acid cycle intermediates for optimization of zeaxanthin production from Flavobacterium multivorum. J. Appl. Microbiol. 2004, 96, 623-629. [CrossRef] [PubMed]

90. Alcantara, S.; Sanchez, S. Influence of carbon and nitrogen sources on Flavobacteriumgrowth and zeaxanthin biosynthesis. J. Ind. Microbiol. Biotechnol. 1999, 23, 697-700. [CrossRef] [PubMed]

91. Asker, D.; Beppu, T.; Ueda, K. Mesoflavibacter zeaxanthinifaciens: A novel zeaxanthin-producing marine bacterium of the family Flavobacteriaceae. Sys. Appl. Microbiol. 2007, 30, 291-296. [CrossRef] [PubMed]

92. Lee, J.H.; Hwang, Y.M.; Baik, K.S.; Choi, K.S.; Ka, J.O.; Seong, C.N. Mesoflavibacter aestuarii sp., a zeaxanthin-producing marine bacterium isolated from seawater. Int. J. Syst. Evol. 2014, 64(Pt. 6), 1932-1937. [CrossRef]

93. Hameed, A.; Shahina, M.; Lin, S.Y.; Lai, W.A.; Hsu, Y.H.; Liu, Y.C.; Young, C.C. Aquibacter zeaxanthinifaciens, a zeaxanthinproducing bacterium of the family Flavobacteriaceae isolated from surface seawater, and emended descriptions of the genera Aestuariibaculum and Gaetbulibacter. Int. J. Syst. Evol. 2014, 64 Pt 1, 138-145. [CrossRef]

94. Misawa, N.; Shimada, H. Metabolic engineering for the production of carotenoids in non-carotenogenic bacteria and yeasts. J. Biotechnol. 1997, 59, 169-181. [CrossRef]

95. Li, X.R.; Tian, G.Q.; Shen, H.J.; Liu, J.Z. Metabolic engineering of Escherichia coli to produce zeaxanthin. J. Ind. Microbiol. Biotechnol. 2015, 42, 627-636. [CrossRef]

96. Asker, D.; Beppu, T.; Ueda, K. Nubsella zeaxanthinifaciens gen. nov., sp. nov., a zeaxanthin-producing bacterium of the family Sphingobacteriaceae isolated from freshwater. Int. J. Syst. Evol. 2008, 58 Pt 3, 601-606. [CrossRef] [PubMed]

97. Hirschberg, J.; Chamovitz, D. Carotenoids in Cyanobacteria. In The Molecular Biology of Cyanobacteria; Kluwer Academic Publishers: Drive Norwell, MA, USA, 1994; pp. 559-579.

98. Morone, J.; Lopes, G.; Preto, M.; Vasconcelos, V.; Martins, R. Exploitation of Filamentous and Picoplanktonic Cyanobacteria for Cosmetic Applications: Potential to Improve Skin Structure and Preserve Dermal Matrix Components. Mar. Drugs 2020, 18, 486. [CrossRef] [PubMed]

99. Mora-Pale, J.M.; Perez-Munguia, S.; Gonzalez-Mejia, J.C.; Dordick, J.S.; Barzana, E. The lipase catalyzed hydrolysis of lutein diesters in nonaqueous media is favoured at extremely low water activities. Biotechnol Bioeng. 2007, 98, 535-542. [CrossRef]

100. Khachik, F. Process for Isolation, Purification and Recrystallization of Lutein from Marigold Oleoresin and Uses Thereof. US Patent 5382714, 17 January 1995.

101. Xu, X.; Shao, B.; Zhou, D.; Ye, S.; Wang, Y.; Chen, B. Process for the Isolation and Purification of Xanthophylls Crystals from Plant Oleoresin. US Patent 7271298B2, 18 September 2007.

102. Yen, H.W.; Sun, C.H.; Ma, T.W. The comparison of lutein production by Scenedesmus sp. in the autotrophic and the mixotrophic cultivation. Appl. Biochem. Biotechnol. 2011, 164, 353-361. [CrossRef]

103. Chen, J.H.; Chen, C.-Y.; Chang, J.-S. Lutein production with wild-type and mutant strains of Chlorella sorokiniana MB-1 under mixotrophic growth. J. Taiwan Inst. Chem. Eng. 2017, 79, 66-73. [CrossRef]

104. Umeno, D.; Tobias, A.V.; Arnold, F.H. Diversifying carotenoid biosynthetic pathways by directed evolution. Microbiol. Mol. Biol. Rev. 2005, 69, 51-78. [CrossRef] [PubMed]

105. Matthews, P.D.; Wurtzel, E.T. Metabolic engineering of carotenoid accumulation in Escherichia coli by modulation of the isoprenoid precursor pool with expression of deoxyxylulose phosphate synthase. Appl. Microbiol. Biotechnol. 2000, 53, 396-400. [CrossRef] [PubMed]

106. Nishizaki, T.; Tsuge, K.; Itaya, M.; Doi, N.; Yanagawa, H. Metabolic engineering of carotenoid biosynthesis in Escherichia coli by ordered gene assembly in Bacillus subtilis. Appl. Enviro. Microbiol. 2007, 73, 1355-1361. [CrossRef] [PubMed]

107. Mohamed, A.; Jansson, C. Influence of light on accumulation of photosynthesis-specific transcripts in the cyanobacterium Synechocystis 6803. Plant Mol. Biol. 1989, 13, 693-700. [CrossRef]

108. Lagarde, D.; Beuf, L.; Vermaas, W. Increased production of zeaxanthin and other pigments by application of genetic engineering techniques to Synechocystis sp. strain PCC 6803. Appl. Environ. Microbiol. 2000, 66, 64-72. [CrossRef] [PubMed] 
109. Takaichi, S.; Maoka, T.; Masamoto, K. Myxoxanthophyll in Synechocystis sp. PCC 6803 is myxol 2'-dimethyl-fucoside, (3R,2'S)myxol 2'-(2,4-di-O-methyl-alpha-L-fucoside), not rhamnoside. Plant Cell Physiol. 2001, 42, 756-762. [CrossRef]

110. Lehmann, M.; Vamvaka, E.; Torrado, A.; Jahns, P.; Dann, M.; Rosenhammer, L.; Aziba, A.; Leister, D.; Rühle, T. Introduction of the Carotenoid Biosynthesis $\alpha$-Branch Into Synechocystis sp. PCC 6803 for Lutein Production. Front. Plant Sci. 2021, $12,699424$. [CrossRef]

111. Baroli, I.; Do, A.D.; Yamane, T.; Niyogi, K.K. Zeaxanthin accumulation in the absence of a functional xanthophyll cycle protects Chlamydomonas reinhardtii from photooxidative stress. Plant Cell 2003, 15, 992-1008. [CrossRef]

112. Baek, K.; Yu, J.; Jeong, J.; Sim, S.J.; Bae, S.; Jin, E. Photoautotrophic production of macular pigment in a Chlamydomonas reinhardtii strain generated by using DNA-free CRISPR-Cas9 RNP-mediated mutagenesis. Biotechnol. Bioeng. 2018, 115, 719-728. [CrossRef]

113. Song, I.; Kim, J.; Baek, K.; Choi, Y.; Shin, B.; Jin, E. The generation of metabolic changes for the production of high-purity zeaxanthin mediated by CRISPR-Cas9 in Chlamydomonas reinhardtii. Microb. Cell Fact. 2020, 19, 220. [CrossRef] [PubMed]

114. Li, R.; Kang, C.; Song, X.; Yu, L.; Liu, D.; He, S.; Zhai, H.; Liu, Q. A ל-carotene desaturase gene, IbZDS, increases $\beta$-carotene and lutein contents and enhances salt tolerance in transgenic sweetpotato. Plant Sci. 2017, 262, 39-51. [CrossRef]

115. Fantini, E.; Falcone, G.; Frusciante, S.; Giliberto, L.; Giuliano, G. Dissection of Tomato Lycopene Biosynthesis through VirusInduced Gene Silencing. Plant Physiol. 2013, 163, 986-998. [CrossRef]

116. Cazzonelli, C.I.; Pogson, B.J. Source to sink: Regulation of carotenoid biosynthesis in plants. Trends Plant Sci. 2010, 15, 266-274. [CrossRef]

117. Blatt, A.; Bauch, M.E.; Pörschke, Y.; Lohr, M. A lycopene $\beta$-cyclase/lycopene $\varepsilon$-cyclase/light-harvesting complex-fusion protein from the green alga Ostreococcus lucimarinus can be modified to produce $\alpha$-carotene and $\beta$-carotene at different ratios. Plant J. 2015, 82, 582-595. [CrossRef] [PubMed]

118. Zeng, J.; Wang, C.; Chen, X.; Zang, M.; Yuan, C.; Wang, X.; Wang, Q.; Li, M.; Li, X.; Chen, L.; et al. The lycopene $\beta$-cyclase plays a significant role in provitamin A biosynthesis in wheat endosperm. BMC Plant Biol. 2015, 15, 112. [CrossRef] [PubMed]

119. Kang, C.; Hong, Z.; Luyao, X.; Ning, Z.; He, S.; Liu, Q. A lycopene $\beta$-cyclase gene, IbLCYB2, enhances carotenoid contents and abiotic stress tolerance in transgenic sweetpotato. Plant Sci. 2018, 272, 243-254. [CrossRef] [PubMed]

120. Albrecht, M.; Misawa, N.; Sandmann, G. Metabolic engineering of the terpenoid biosynthetic pathway of Escherichia coli for production of the carotenoids beta-carotene and zeaxanthin. Biotechnol. Lett. 1999, 21, 791-795. [CrossRef]

121. Li, R.; Turner, S.D.; Brautigan, D.L. Xanthophylls lutein and zeaxanthin modify gene expression and induce synthesis of hyaluronan in keratinocyte model of human skin. Biochem. Biophys. Rep. 2015, 4, 52-58. [CrossRef]

122. Zia-Ul-Haq, M.; Riaz, M.; Ahmedah, H.T. Carotenoids and Periodontal Diseases. In Carotenoids: Structure and Function in the Human Body; Zia-Ul-Haq, M., Dewanjee, S., Riaz, M., Eds.; Springer: Cham, Switzerland, 2021; pp. 715-720.

123. Yu, B.; Lydiate, D.J.; Young, L.W.; Schäfer, U.A.; Hannoufa, A. Enhancing the carotenoid content of Brassica napus seeds by downregulating lycopene epsilon cyclase. Transgenic Res. 2008, 17, 573-585. [CrossRef]

124. Atienza, S.G.; Ballesteros, J.; Martín, A.; Hornero-Méndez, D. Genetic variability of carotenoid concentration and degree of esterification among tritordeum (xTritordeum Ascherson et Graebner) and durum wheat accessions. J. Agric. Food Chem. 2007, 55, 4244-4251. [CrossRef] [PubMed]

125. Rodrigues, D.B.; Mercadante, A.Z.; Mariutti, L. Marigold carotenoids: Much more than lutein esters. Food Res. Int. (Ottawa, Ont.) 2019, 119, 653-664. [CrossRef] [PubMed]

126. Mares, D.J.; Campbell, A.W. Mapping components of flour and noodle colour in Australian wheat. Aust. J. Agric. Res. 2001, 52, 1297-1309 101071/AR01048. [CrossRef]

127. Bone, R.A.; Landrum, J.T.; Friedes, L.M.; Gomez, C.M.; Kilburn, M.D.; Vidal, E.M.; Wang, W. Distribution of lutein and zeaxanthin stereoisomers in the human retina. Exp. Eye Res. 1997, 64, 211-218. [CrossRef]

128. Abdel-Aal, E.S.M.; Young, J.C.; Akhtar, H.; Rabalski, I. Stability of lutein in wholegrain bakery products naturally high in lutein or fortified with free lutein. J. Agric. Food. Chem. 2010, 58, 10109-10117. [CrossRef]

129. Hidalgo, A.; Brandolini, A. Kinetics of carotenoid degradation during the storage of Einkorn (Triticum monococcum L. ssp monococcum) and bread wheat (Triticum aestivum L. ssp. aestivum) flours. J. Agric. Food Chem. 2008, 56, 11300-11305. [CrossRef]

130. Zia-Ul-Haq, M.; Riaz, M.; Modhi, A.O. Carotenoids and Bone Health. In Carotenoids: Structure and Function in the Human Body; Zia-Ul-Haq, M., Dewanjee, S., Riaz, M., Eds.; Springer: Cham, Switzerland, 2021; pp. 697-713.

131. Requena-Ramírez, M.D.; Atienza, S.G.; Hornero-Méndez, D.; Rodríguez-Suárez, C. Mediation of a GDSL Esterase/Lipase in Carotenoid Esterification in Tritordeum Suggests a Common Mechanism of Carotenoid Esterification in Triticeae Species. Front. Plant Sci. 2020, 11, 592515. [CrossRef] [PubMed]

132. Watkins, J.L.; Li, M.; McQuinn, R.P.; Chan, K.X.; McFarlane, H.E.; Ermakova, M.; Furbank, R.T.; Mares, D.; Dong, C.; Chalmers, K.J.; et al. A GDSL Esterase/Lipase Catalyzes the Esterification of Lutein in Bread Wheat. Plant Cell 2019, 31, $3092-3112$. [CrossRef] [PubMed]

133. Ziegler, J.U.; Wahl, S.; Würschum, T.; Longin, C.F.H.; Carle, R.; Schweiggert, R.M. Lutein and lutein esters in whole grain flours made from 75 genotypes of 5 triticum species grown at multiple sites. J. Agric. Food Chem. 2015, 63, 5061-5071. [CrossRef]

134. Shangguan, H.; Zhang, S.; Li, X.; Zhou, Q.; Shi, J.; Deng, Q.; Huang, F. Synthesis of lutein esters using a novel biocatalyst of Candida antarctica lipase B covalently immobilized on functionalized graphitic carbon nitride nanosheets. RSC Adv. 2020, 10, 8949-8957. [CrossRef] 
135. Gombač, Z.; Črnivec, I.; Skrt, M.; Istenič, K.; Knafelj, A.K.; Pravst, I.; Ulrih, N.P. Stabilisation of Lutein and Lutein Esters with Polyoxyethylene Sorbitan Monooleate, Medium-Chain Triglyceride Oil and Lecithin. Foods 2021, 10, 500. [CrossRef]

136. Weller, P.; Breithaupt, D.E. Identification and quantification of zeaxanthin esters in plants using liquid chromatograph-mass spectrometry. J Agric. Food Chem. 2003, 51, 7044-7049. [CrossRef]

137. Zhou, L.; Leung, I.; Tso, M.O.; Lam, K.W. The identification of dipalmityl zeaxanthin as the major carotenoid in Gou Qi Zi by high pressure liquid chromatography and mass spectrometry. J. Ocul. Pharmacol. Ther. 1999, 15, 557-565. [CrossRef] [PubMed]

138. Breithaupt, D.E.; Weller, P.; Wolters, M.; Hahn, A. Comparison of plasma responses in human subjects after the ingestion of 3R, 3R'zeaxanthin dipalmitate from wolfberry (Lycium barbarum) and non-esterified $3 R, 3 R^{\prime}$-zeaxanthin using chiral high-performance liquid chromatography. Br. J. Nutr. 2004, 91, 707-713. [CrossRef] [PubMed]

139. Lam, K.W.; But, P. The content of zeaxanthin in Gou Qi Zi, a potential health benefit to improve visual acuity. Food Chem. 1999, 67, 173-176. [CrossRef]

140. Leung, I.Y.F.; Ngai, J.; Lam, K.W.; Tso, M.O.M. Absorption of zeaxanthin in rats after feeding with purified zeaxanthin or a traditional Chinese medicine, Gou Qi Zi. In Vest. Ophthalmol. Vis. Sci. 1999, 40, S608.

141. Wingerath, T.; Stahl, W.; Kirsch, D.; Kaufmann, R.; Sies, H. Fruit juice carotenol fatty acid esters and carotenoids as identified by matrix-assisted laser desorption ionization (MALDI) mass spectrometry. J. Agric. Food Chem. 1996, 44, 2006-2013. [CrossRef]

142. Dey, T.K.; Maiti, I.; Chakraborty, S.; Ghosh, M.; Dhar, P. Enzymatic synthesis of lipophilic lutein-PUFA esters and assessment of their stabilization potential in EPA-DHA rich fish oil matrix. J. food Sci. Technol. 2019, 56, 2345-2354. [CrossRef]

143. Wu, M.; Feng, Z.; Deng, Y.; Zhong, C.; Liu, Y.; Liu, J.; Zhao, X.; Fu, Y. Liquid antisolvent precipitation: An effective method for ocular targeting of lutein esters. Int. J. Nanomed. 2019, 14, 2667-2681. [CrossRef] [PubMed]

144. Kuang, P.; Zhang, H.; Bajaj, P.R.; Yuan, Q.; Tang, J.; Chen, S.; Sablani, S.S. Physicochemical properties and storage stability of lutein microcapsules prepared with maltodextrins and sucrose by spray drying. J. Food Sci. 2015, 80, E359-E369. [CrossRef] [PubMed]

145. Zhao, C.; Cheng, H.; Jiang, P.; Yao, Y.; Han, J. Preparation of lutein-loaded particles for improving solubility and stability by Polyvinylpyrrolidone (PVP) as an emulsion-stabilizer. Food Chem. 2014, 156, 123-128. [CrossRef] [PubMed]

146. Tudor, C.; Bohn, T.; Iddir, M.; Dulf, F.V.; Focssan, M.; Rugină, D.O.; Pintea, A. Sea Buckthorn Oil as a Valuable Source of Bioaccessible Xanthophylls. Nutrients 2020, 12, 76. [CrossRef] [PubMed]

147. Ligia Focsan, A.; Polyakov, N.E.; Kispert, L.D. Supramolecular Carotenoid Complexes of Enhanced Solubility and Stability - The Way of Bioavailability Improvement. Molecules 2019, 24, 3947. [CrossRef]

148. Aparicio-Ruiz, R.; Mínguez-Mosquera, I.; Rojas, G.; Gandul-Rojas, B. Thermal degradation kinetics of lutein, $\beta$-carotene and $\beta$-cryptoxanthin in virgin olive oils. J. Food Compos. Anal. 2011, 24, 811-820. [CrossRef]

149. Verhoeven, A. Sustained energy dissipation in winter evergreens. New Phytol. 2014, 201, 57-65. [CrossRef]

150. Sofronova, V.E.; Dymova, O.V.; Golovko, T.K.; Chepalov, V.A.; Petrov, K.A. Adaptive changes in pigment complex of Pinus sylvestris needles upon cold acclimation. Russ. J. Plant Physiol. 2016, 63, 433-442. [CrossRef]

151. Krinsky, N.I.; Johnson, E.J. Carotenoid actions and their relation to health and disease. Mol. Asp. Med. 2005, 26, 459-516. [CrossRef]

152. Vishwanathan, R.; Iannaccone, A.; Scott, T.M.; Kritchevsky, S.B.; Jennings, B.J.; Carboni, G.; Forma, G.; Satterfield, S.; Harris, T.; Johnson, K.C.; et al. Macular pigment optical density is related to cognitive function in older people. Age Ageing 2014, 43, 271-275. [CrossRef] [PubMed]

153. Johnson, E.J.; Vishwanathan, R.; Johnson, M.A.; Hausman, D.B.; Davey, A.; Scott, T.M.; Green, R.C.; Miller, L.S.; Gearing, M.; Woodard, J. Relationship between serum and brain carotenoids, $\alpha$-tocopherol, and retinol concentrations and cognitive performance in the oldest old from the georgia centenarian study. J. Aging Res. 2013, 2013, 951786. [CrossRef] [PubMed]

154. Feeney, J.; Finucane, C.; Savva, G.M.; Cronin, H.; Beatty, S.; Nolan, J.M.; Kenny, R.A. Low macular pigment optical density is associated with lower cognitive performance in a large, population-based sample of older adults. Neurobiol. Aging 2013, 34, 2449-2456. [CrossRef]

155. Bovier, E.R.; Renzi, L.M.; Hammond, B.R. A double-blind, placebo-controlled study on the effects of lutein and zeaxanthin on neural processing speed and efficiency. PLoS ONE 2014, 9, e108178. [CrossRef]

156. Johnson, E.J.; McDonald, K.; Caldarella, S.M. Cognitive findings of an exploratory trial of docosahexaenoic acid and lutein supplementation in older women. Nutr. Neurosci. 2008, 11, 75-83. [CrossRef]

157. Stahl, W.; Seis, H. Effects of carotenoids and retinoids on gap junctional communication. Biofactors 2001, 15, 95-98. [CrossRef] [PubMed]

158. Hammond, B.R., Jr.; Wooten, B.R. CFF Thresholds: Relation to macular pigment optical density. Ophthalmic Physiol. Opt. 2005, 25, 315-319. [CrossRef] [PubMed]

159. Fatani, A.J.; Al-Rejaie, S.S.; Parmar, M.Y.; Ahmed, O.M.; Abuohashish, H.M.; Ahmed, M.M. Lutein attenuates diabetic-induced renal damage via inhibiting oxidative and nitrosative stresses. Progr. Nutr. 2017, 19, 57-66.

160. Hu, B.J.; Hu, Y.N.; Lin, S.; Ma, W.J.; Li, X.R. Application of Lutein and Zeaxanthin in nonproliferative diabetic retinopathy. Int. J. Ophthalmol. 2011, 4, 303-306. [PubMed]

161. Mares-Perlman, J.A.; Brady, W.E.; Klein, B.E.K.; Klein, R.; Haus, G.J.; Palta, M.; Ritter, L.L.; Shoff, S.M. Diet and nuclear lens opacities. Am. J. Epidemiol. 1995, 141, 322-334. [CrossRef] 
162. Lyle, B.J.; Mares-Perlman, J.A.; Klein, B.E.K.; Klein, R.; Palta, M.; Bowen, P.E.; Greger, J.L. Serum carotenoids and tocopherols and incidence of age-related nuclear cataract. Am. J. Clin. Nutr. 1999, 69, 272-277. [CrossRef]

163. Olmedilla, B.; Granado, F.; Blanco, I.; Herrero, C.; Vaquero, M.; Millan, I. Serum status of carotenoids and tocopherols in patients with age-related cataracts: A case-control study. J. Nutr. Health Aging 2002, 6, 66-68.

164. Slattery, M.L.; Benson, J.; Curtin, K.; Ma, K.; Schaeffer, D.; Potte, R.J.D. Carotenoids and colon cancer. Am. J. Clin. Nutr. 2000, 71, 575-582. [CrossRef]

165. Le Marchand, L.; Franke, A.A.; Custer, L.; Wilkens, L.R.; Cooney, R.V. Lifestyle and nutritional correlates of cytochrome CYP1A2 activity. Inverse associations with plasma lutein and alphatocopherol. Pharmacogenetics 1997, 7, 11-19. [CrossRef] [PubMed]

166. Kim, J.M.; Araki, S.; Kim, D.J.; Park, C.B.; Takasuka, N.; Baba-Toriyama, H.; Ota, T.; Nir, Z.; Khachik, F.; Shimidzu, N.; et al. Chemopreventive effects of carotenoids and curcumins on mouse colon carcinogenesis after 1,2-dimethylhydrazine initiation. Carcinogenesis 1998, 19, 81-85. [CrossRef] [PubMed]

167. Haegele, A.D.; Gillette, C.; O’Neill, C.; Wolfe, P.; Heimendinger, J.; Sedlacek, S.; Thompson, H.J. Plasma xanthophyll carotenoids correlate inversely with indices of oxidative DNA damage and lipid peroxidation. Cancer Epidemiol. Biomark. Prev. 2000 $9,421-425$.

168. Zhang, M.; Holman, C.D.; Binns, C.W. Intake of specific carotenoids and the risk of epithelial ovarian cancer. Br. J. Nutr. 2007, 98, 187-193. [CrossRef] [PubMed]

169. Gohar, U.F.; Iqbal, I.; Shah, Z.; Mukhtar, H.; Zia-Ul-Haq, M. COVID-19: Recent Developments in Therapeutic Approaches. In Alternative Medicine Interventions for COVID-19; Zia-Ul-Haq, M., Bin-Jumah, M.N., Alothamn, S.I., Henidi, H.A., Eds.; Springer: Cham, Switzerland, 2021; pp. 249-274.

170. Wang, Q.; Wang, X.; Hernandez, A.; Kim, S.; Evers, B.M. Inhibition of the phosphatidylinositol 3-kinase pathway contributes to HT29 and Caco-2 intestinal cell differentiation. Gastroenterology 2001, 120, 1543-1546. [CrossRef]

171. Rock, C.L.; Saxe, G.A.; Ruffin, M.T.; August, D.A.; Schottenfeld, D. Carotenoids, vitamin A, and estrogen receptor status in breast cancer. Nutr. Cancer 1996, 25, 281-296. [CrossRef]

172. Ribaya-Mercado, J.D.; Blumberg, J.B. Lutein and Zeaxanthin and Their Potential Roles in Disease Prevention. J. Am. Coll. Nutr. 2004, 23, 567S-587S. [CrossRef]

173. Gong, X.; Smith, J.; Swanson, H.; Rubin, L. Carotenoid Lutein Selectively Inhibits Breast Cancer Cell Growth and Potentiates the Effect of Chemotherapeutic Agents through ROS-Mediated Mechanisms. Molecules 2018, 23, 905. [CrossRef]

174. Park, J.S.; Chew, B.P.; Wong, T.S. Dietary lutein from marigold extract inhibits mammary tumor development in BALB/c mice. J. Nutr. 1998, 128, 1650-1656. [CrossRef] [PubMed]

175. Gao, B.; Ahmad, M.F.; Nagy, L.E.; Tsukamoto, H. Inflammatory pathways in alcoholic steatohepatitis. J. Hepatol. 2019, 70, 249-259. [CrossRef]

176. Xiao, J.; Wang, J.; Xing, F.; Han, T.; Jiao, R.; Liong, E.C.; Fung, M.-L.; So, K.-F.; Tipoe, G.L. Zeaxanthin dipalmitate therapeutically improves hepatic functions in an alcoholic fatty liver disease model through modulating MAPK pathway 9, no. 4, Article ID e95214, 2014. PLoS ONE 2014, 9, e95214. [CrossRef] [PubMed]

177. Chamberlain, S.M.; Hall, J.D.; Patel, J. Protective effects of the carotenoid zeaxanthin in experimental nonalcoholic steatohepatitis. Dig. Dis. Sci. 2009, 54, 1460-1464. [CrossRef]

178. Zielińska, M.A.; Wesołowska, A.; Pawlus, B.; Hamułka, J. Health Effects of Carotenoids during Pregnancy and Lactation. Nutrients 2017, 9, 838. [CrossRef] [PubMed]

179. Mahmassani, H.A.; Switkowski, K.M.; Scott, T.M.; Johnson, E.J.; Rifas-Shiman, S.L.; Oken, E.; Jacques, P.F. Maternal Intake of Lutein and Zeaxanthin during Pregnancy Is Positively Associated with Offspring Verbal Intelligence and Behavior Regulation in Mid-Childhood in the Project Viva Cohort. J. Nutr. 2021, 151, 615-627. [CrossRef]

180. Mortensen, A. Supplements. In Carotenoids. Nutrition and Health; Britton, G., Pfander, H., Liaaen-Jensen, S., Eds.; Birkhäuser: Basel, Switzerland, 2009; Volume 5, pp. 67-82.

181. Brantsæter, A.L.; Haugen, M.; Rasmussen, S.E.; Alexander, J.; Samuelsen, S.O.; Meltzer, H.M. Urine flavonoids and plasma carotenoids in the validation of fruit, vegetable and tea intake during pregnancy in the Norwegian Mother and Child Cohort Study (MoBa). Public Health Nutr. 2007, 10, 838-847. [CrossRef] [PubMed]

182. Soy, M.; Keser, G.; Atagündüz, P.; Tabak, F.; Atagündüz, I.; Kayhan, S. Cytokine storm in COVID-19: Pathogenesis and overview of anti-inflammatory agents used in treatment. Clin. Rheumatol. 2020, 39, 2085-2094. [CrossRef]

183. Guzik, B.; Berry, C.; Touyz, R.M.; Kreutz, R.; Wang, D.W.; McInnes, I.B. COVID-19 and the cardiovascular system: Implications for risk assessment, diagnosis, and treatment options. Cardiovasc. Res. 2020, 116, 1666-1687. [CrossRef]

184. Walston, J.; Xue, Q.; Semba, R.D.; Ferrucci, L.; Cappola, A.R.; Ricks, M.; Guralnik, J.; Fried, L.P. Serum antioxidants, inflammation, and total mortality in older women. Am. J. Epidemiol. 2006, 163, 18-26. [CrossRef] [PubMed]

185. Ozawa, Y.; Sasaki, M.; Takahashi, N.; Kamoshita, M.; Miyake, S.; Tsubota, K. Neuroprotective effects of lutein in the retina. Curr. Pharm. Des. 2012, 18, 51-56. [CrossRef]

186. Ambati, J.; Anand, A.; Fernandez, S.; Sakurai, E.; Lynn, B.C.; Kuziel, W.A.; Rollins, B.J.; Ambati, B.K. An animal model of age-related macular degeneration in senescent Ccl-2- or Ccr-2-deficient mice. Nat. Med. 2003, 9, 1390-1397. [CrossRef] [PubMed]

187. Kamoshita, M.; Toda, E.; Osada, H.; Narimatsu, T.; Kobayashi, S.; Tsubota, K.; Ozawa, Y. Lutein acts via multiple antioxidant pathways in the photo-stressed retina. Sci. Rep. 2016, 6, 30226. [CrossRef] [PubMed] 
188. Sachdeva, M.M.; Cano, M.; Handa, J.T. Nrf 2 signaling is impaired in the aging RPE given an oxidative insult. Exp. Eye Res. 2014, 119, 111-114. [CrossRef] [PubMed]

189. Zhang, M.; An, C.; Gao, Y.; Leak, R.K.; Chen, J.; Zhang, F. Emerging roles of Nrf 2 and phase II antioxidant enzymes in neuroprotection. Prog. Neurobiol. 2013, 100, 30-47. [CrossRef]

190. Itoh, K.; Wakabayashi, N.; Katoh, Y.; Ishii, T.; Igarashi, K.; Engel, J.D.; Yamamoto, M. Keap1 represses nuclear activation of antioxidant responsive elements by Nrf 2 through binding to the amino-terminal Neh2 domain. Genes Dev. 1999, 13, 76-86. [CrossRef] [PubMed]

191. Li, Z.; Dong, Z.; Liu, H.; Chen, X.; Shi, H.; Fan, Y.; Hou, D.; Zhang, X. Astaxanthin protects ARPE-19 cells from oxidative stress via upregulation of Nrf 2-regulated phase II enzymes through activation of PI3K/Akt. Mol. Vis. 2013, 19, $1656-1666$.

192. Frede, K.; Ebert, F.; Kipp, A.P.; Schwerdtle, T.; Baldermann, S. Lutein Activates the Transcription Factor Nrf2 in Human Retinal Pigment Epithelial Cells. J. Agric. Food Chem. 2017, 65, 5944-5952. [CrossRef]

193. Sun, J.K.; Glassman, A.R.; Beaulieu, W.T.; Stockdale, C.R.; Bressler, N.M.; Flaxel, C.; Gross, J.G.; Shami, M.; Jampol, L.M. Diabetic Retinopathy Clinical Research Network, Rationale and Application of the Protocol S Anti-Vascular Endothelial Growth Factor Algorithm for Proliferative Diabetic Retinopathy. Ophthalmology 2019, 126, 87-95. [CrossRef]

194. Keegan, G.; Pardhan, S.; Chichger, H. Lutein and zeaxanthin attenuates VEGF-induced neovascularisation in human retinal microvascular endothelial cells through a Nox4-dependent pathway. Exp. Eye Res. 2020, 197, 108104. [CrossRef]

195. Serrander, L.; Cartier, L.; Bedard, K.; Banfi, B.; Lardy, B.; Plastre, O.; Sienkiewicz, A.; Forro, L.; Schlegel, W.; Krause, K.H. NOX4 activity is determined by mRNA levels and reveals a unique pattern of ROS generation. Biochem. J. 2007, 406, 105-114. [CrossRef] [PubMed]

196. Kaneko, H.; Dridi, S.; Tarallo, V. DICER1 deficit induces Alu RNA toxicity in age-related macular degeneration. Nature 2011, 471, 325-330. [CrossRef]

197. Halliwell, B.; Clement, M.V.; Long, L.H. Hydrogen peroxide in the human body. FEBS Lett. 2000, 486, 10-13. [CrossRef]

198. Zareba, M.; Raciti, M.W.; Henry, M.M.; Sarna, T.; Burke, J.M. Oxidative stress in ARPE-19 cultures: Do melanosomes confer cytoprotection? Free Radic. Biol. Med. 2006, 40, 87-100. [CrossRef]

199. Chong, Y.S.; Mai, C.W.; Leong, C.O.; Wong, L.C. Lutein improves cell viability and reduces Alu RNA accumulation in hydrogen peroxide challenged retinal pigment epithelial cells. Cutan. Ocul. Toxicol. 2018, 37, 52-60. [CrossRef] [PubMed]

200. Kuo, L.M.; Chen, P.J.; Sung, P.J. The bioactive extract of Pinnigorgia sp induces apoptosis of hepatic stellate cells via ROS-ERK/JNKCaspase-3 signaling. Mar. Drugs 2018, 16, 19. [CrossRef] [PubMed]

201. Krasilnikov, M.; Ivanov, V.N.; Dong, J. ERK and PI3K negatively regulate STAT-transcriptional activities in human melanoma cells: Implications towards sensitization to apoptosis. Oncogene 2003, 22, 4092-4101. [CrossRef] [PubMed]

202. Poage, M.; Le Martret, B.; Jansen, M.A.; Nugent, G.D.; Dix, P.J. Modification of reactive oxygen species scavenging capacity of chloroplasts through plastid transformation. Plant. Mol. Biol. 2011, 76, 371-384. [CrossRef]

203. Sheng, Y.N.; Luo, Y.H.; Liu, S.B.; Xu, W.T.; Zhang, Y.; Zhang, T.; Xue, H.; Zuo, W.B.; Li, Y.N.; Wang, C.Y.; et al. Zeaxanthin Induces Apoptosis via ROS-Regulated MAPK and AKT Signaling Pathway in Human Gastric Cancer Cells. OncoTargets Ther. 2020, 13, 10995-11006. [CrossRef]

204. Wang, K.; Chu, D.; Wu, J.; Zhao, M.; Zhang, M.; Li, B.; Du, W.; Du, J.; Guo, R. Cinobufagin induced cell apoptosis and protective autophagy through the ROS/MAPK signaling pathway. Life Sci. 2019. [CrossRef]

205. Rapp, L.M.; Maple, S.S.; Choi, J.H. Lutein and zeaxanthin concentrations in rod outer segment membranes from perifoveal and peripheral human retina. Invest. Ophthalmol. Vis. Sci. 2000, 41, 1200-1209.

206. Dufossé, L.; Galaup, P.; Yaron, A.; Arad, S.M.; Blanc, P.; Murthy, K.N.C.; Ravishankar, G.A. Microorganisms and microalgae as sources of pigments for food use: A scientifc oddity or an industrial reality? Trends Food Sci. Technol. 2005, 16, 389-406. [CrossRef]

207. Karmakar, A.; Das, A.K.; Ghosh, S.; Sil, P.C. Carotenoids as Coloring Agents. In Carotenoids: Structure and Function in the Human Body; Zia-Ul-Haq, M., Dewanjee, S., Riaz, M., Eds.; Springer: Cham, Switzerland, 2021. [CrossRef]

208. Saini, R.K.; Keum, Y.S. Progress in microbial carotenoids production. Indian J. Microbiol. 2017, 57, 129-130. [CrossRef] [PubMed]

209. Lebeau, J.; Venkatachalam, M.; Fouillaud, M.; Petit, T.; Vinale, F.; Dufossé, L.; Yanis, C. Production and new extraction method of polyketide red pigments produced by Ascomycetes fungi from terrestrial and marine habitats. J. Fungi 2017, 3, 34. [CrossRef]

210. Dayal, R.; Dobhal, P.C. Natural dyes from some Indian plants. Colourage 2001, 48, 33-38.

211. Adeel, S.; Gulzar, T.; Azeem, M.; Rehman, F.; Saeed, M.; Hanif, I.; Iqbal, N. Appraisal of marigold flower based leutin as natural colourant for textile dyeing under the influence of gamma radiations. Radiat. Phys. Chem. 2017, 130, 35-39. [CrossRef]

212. Levy, L.; Inventor, W. Trans-Xanthophyll Ester Concentrates of Enhanced Purity and Methods of Making Same. Inexa Industria Extractora, C.A., Assignee. US Patent 6191293B1, 20 February 2001.

213. Bailey, C.A.; Chen, B.H. Chromatographic analyses of xanthophylls in egg yolks from laying hens fed turf Bermuda grass (Cynodon dactylon) meal. J. Food Sci. 1989, 54, 584-586. [CrossRef]

214. Hencken, H. Chemical and physiological behavior of feed carotenoids and their effects on pigmentation. Poult. Sci. 1992, 71, 711-717. [CrossRef]

215. Tyczkowski, J.K.; Hamilton, P.B. Absorption, transport, and digestion in chickens of lutein diester, a carotenoid extracted from marigold (Tagetes erecta) petals. Poult. Sci. 1986, 65, 1526-1531. [CrossRef] [PubMed]

216. Wang, L.; Xue, M.; Wang, J.; Wu, X.; Zheng, Y.; Cao, C. Effect of natural xanthophylls on growth performance and body pigmentation of yellow catfish (Pelteobagrus fulvidraco). J. Fish. China 2012, 36, 1102-1110. [CrossRef] 
217. Nelis, J.H.; DeLeenheer, P.A. Microbial sources of carotenoid pigments used in foods and feeds. J. Appl. Bacteriol. 1991, 70, 181-191. [CrossRef]

218. Tabor, A.; Blair, R. Nutritional Cosmetics: Beauty from within; William Andrew: Norwich, NY, USA, 2009 ; pp. 185-198.

219. Bin-Jumah, M.; Alwakeel, S.S.; Moga, M.; Buvnariu, L.; Bigiu, N.; Zia-Ul-Haq, M. Application of Carotenoids in Cosmetics. In Carotenoids: Structure and Function in the Human Body; Zia-Ul-Haq, M., Dewanjee, S., Riaz, M., Eds.; Springer: Cham, Switzerland, 2021. [CrossRef]

220. Shen, H.J.; Cheng, B.Y.; Zhang, Y.M.; Tang, L.; Li, Z.; Bu, Y.F.; Li, X.R.; Tian, G.Q.; Liu, J.Z. Dynamic control of the mevalonate pathway expression for improved zeaxanthin production in Escherichia coli and comparative proteome analysis. Metab. Eng. 2016, 38, 180-190. [CrossRef]

221. Du, W.; Song, Y.; Liu, M.; Yang, H.; Zhang, Y.; Fan, Y.; Luo, X.; Li, Z.; Wang, N.; He, H.; et al. Gene expression pattern analysis of a recombinant Escherichia coli strain possessing high growth and lycopene production capability when using fructose as carbon source. Biotechnol. Lett. 2016, 38, 1571-1577. [CrossRef] [PubMed]

222. Furubayashi, M.; Ikezumi, M.; Takaichi, S.; Maoka, T.; Hemmi, H.; Ogawa, T.; Saito, K.; Tobias, A.V.; Umeno, D. A highly selective biosynthetic pathway to non-natural C 50 carotenoids assembled from moderately selective enzymes. Nat. Commun. 2015, 6, 7534. [CrossRef] [PubMed] 